Working Paper Series

642

(ISSN 1211-3298)

Worker Heterogeneity and

the Asymmetric Effects of

Minimum Wages

Jose Luis Luna-Alpizar

CERGE-EI

Prague, May 2019 
ISBN 978-80-7343-449-6 (Univerzita Karlova, Centrum pro ekonomický výzkum a doktorské studium)

ISBN 978-80-7344-502-7 (Národohospodářský ústav AV ČR, v. v. i.) 


\title{
Worker Heterogeneity and the Asymmetric Effects of Minimum Wages
}

\author{
Jose Luis Luna-Alpizar* \\ CERGE-EI
}

April 2019

\begin{abstract}
This paper explores the notion that minimum wages affect different lowskilled workers asymmetrically due to productivity differences. In a search model with worker heterogeneity, a rising minimum wage lowers the employment and labor force participation of the least productive workers by pricing them out of the market, while having the opposite effect on other low-skilled workers that remain hirable. CPS data supports these predictions; a rise in the minimum reduces the employment and labor force participation of teenagers with less than high school education, but has the opposite effect on prime-age workers with high school attainment. The calibrated model requires small firm surpluses to match these observations. If firm surplus is small due to high nonmarket activity values, a moderate rise in the minimum improves aggregate welfare even when the worker's bargaining weight is high.
\end{abstract}

Keywords: Minimum Wages, Search and Matching, Unemployment, Worker Heterogeneity

JEL Classification: E24, J08, J38, J64, J68

\footnotetext{
${ }^{*}$ CERGE-EI, a joint workplace of Charles University and the Economics Institute of the Czech Academy of Sciences, Politickych veznu 7, 11121 Prague, Czech Republic, email: j1.luna.alpizar@gmail.com. I thank Guillaume Rocheteau, William Branch, Eric Swanson, David Neumark, and the participants at the UCI Macroeconomics Workshop for their invaluable advice and support. I also thank Nicolas Petrosky-Nadeau, Pascal Michaillat, and all the participants of the 2015 West Coast Search and Matching Meeting at the Federal Reserve Bank of San Francisco. I benefited from the helpful inputs of Christopher Flinn, Pierre Cahuc, Moritz Kuhn, and all the participants of the IZA/CREST/Bonn University Workshop: Employment Policies and Heterogeneity in the Labor Market. Special thanks to the participants at the CERGE-EI Macroeconomics Seminar and the FAU/IAB Macroeconomics and Labor Markets Seminar. All errors are my own.
} 


\section{Introduction}

The effects of minimum wages on labor markets have been extensively investigated with mixed, and often conflicting, results. ${ }^{1}$ Underlying the small or null employment loss that most quasi-experimental studies document, there could be important compositional effects that are missed by the implicit assumption in many of these studies of a homogeneous low-skilled labor force. From part-time teenagers to pensioners, low-wage occupations attract workers with diverse levels of experience, education and aptitude. Incorporating such heterogeneity into the analysis of any policy is necessary to fully describe its impact.

This paper explores the notion that minimum wages affect low-skilled workers asymmetrically due to differences in their productivity. ${ }^{2}$ We present a search model with ex ante worker heterogeneity based on the Pissarides (2000) framework. Undirected search, Nash-bargaining wages, and endogenous search intensity generate a variety of participation and employment rates, and wages. With such diversity in outcomes, an increase in the minimum wage affects workers differently, depending on their relative position in the productivity distribution.

A rising minimum prices out the least productive workers, who in turn find it optimal to exit the labor force. Workers with productivities high enough to remain hirable, but with wages sufficiently low to be overridden by the new minimum, experience an exogenous wage increase. Thus, the policy has two opposing effects on the firm's incentive to create vacancies. On the one hand, it increases average worker productivity by driving the least productive workers out of the labor force, this being the "trim" effect. On the other hand, it exogenously increases the cost of labor, producing the wage "bump" effect. ${ }^{3}$ Therefore, the policy's impact on market tightness, defined as the ratio of open

${ }^{1}$ See Neumark and Wascher (2007), Neumark and Wascher (2008), and Belman and Wolfson (2014) for an extensive literature survey. See Doucouliagos and Stanley (2009) for a meta-analysis.

${ }^{2}$ Our central proposition is by no means new; we theoretically describe and provide further evidence of a phenomenon known in the labor economics literature for over a century. Obcnaucr and von der Nienburg (1915) study the effects of the introduction of a minimum wage for women in Oregon between October 1913 and February 1914. 'I'hey conclude that despite the fact that the implementation of the policy had little effect on aggregate lowskilled female employment, its impact was asymmetric across women since it reduced the employability of teenage girls in favor of adult women.

${ }^{3}$ Similar in spirit, Drazen (1986) presents a model where an increase in the minimum generates gains in worker quality that could outweigh the increase in labor costs and lead to Pareto improvements. 
vacancies to job searchers, is ambiguous.

Whether the market tightens or slackens depends to a great extent on the wedge between unconstrained Nash wages and productivity. When the wedge is wide, the constraint of the minimum binds for many workers, so the "bump" effect outweighs the gains in average worker-productivity; the market will slacken. With a narrow wedge, the "bump" effect is limited, and can be outweighed by gains in average productivity; the market will tighten.

The impact on market tightness determines the intra-labor force welfare implications. In a slacker market, the most productive workers, those with unconstrained wages above the new minimum, experience a reduction in their employment prospects, a drop in their participation rates, and lower wages because of their eroded job opportunities. However, those bound by the new minimum receive higher wages and could increase their employment and participation if the impact on tightness is not too negative. In this way, a higher minimum would reduce welfare inequality among hirable workers. In the opposite case, if the market tightens, all hirable workers experience higher employment, participation, and wages at the expense of those priced out, the least productive workers. This not only widens the welfare gap between hirable and non-hirable, but also within the hirable. This is the main result of our model, that a higher minimum has the potential to generate asymmetric, in fact diametrically opposed, effects on individual market outcomes that can either reduce, in the case of a slacker market, or enhance, in the case of a tighter market, the welfare difference between the most and least productive low-skilled workers.

Motivated by our model, we investigate whether a rise in the minimum affects different low-skilled workers asymmetrically. We estimate its impact on employment, labor force participation, and wages disaggregating by educational attainment and age. In this regard, we extend the standard analysis of the policy's employment effect on teenagers by also investigating its impact on the labor force participation of other low-education demographics that are often overlooked.

Using quasi-experimental methods and Current Population Survey (CPS) data, we find that increments in the minimum wage have asymmetric effects within the low-education labor force; they reduce the employment and labor force participation of teenagers with less than a high school education, while increasing the employment and labor force participation of prime-aged workers with high school attainment. ${ }^{4}$ While the negative effects on teenage market

\footnotetext{
${ }^{4}$ These contrasting results are in line with other works documenting some substitution effect among workers earning the minimum. The idea that an increase in the minimum
} 
outcomes have been reported by previous studies, the positive impact on loweducation prime-age labor outcomes is, to be best of our knowledge, new in the literature. ${ }^{5}$

The contrast in outcomes is explained by our model, from which we conclude: i) low-education workers participate in the same labor market and both, negative and positive impacts, are connected through a general equilibrium effect; a trimming of teenagers off the labor force, and an ensuing tightening of the market that benefits low education prime-age workers, and ii) the wedge between unconstrained wages and productivity must be relatively small for the tightening to occur.

To perform welfare analysis, we calibrate the model to match key loweducation labor statistics. Chief among them is the positive employment elasticity with respect to the minimum wage of low-education prime-age workers. The calibration requires a small expected firm surplus to match the sign and magnitude of this elasticity. The reason is twofold. First, a small firm surplus implies a narrow wedge between the unconstrained wages and productivity; the direct wage "bump" is small relative to the gains in expected worker productivity, and thus the market tightens. Second, it is well known in the literature that if firm surplus is small, vacancy posting responds strongly to changes in expected match productivity; a small firm surplus also guarantees that the market tightens enough. ${ }^{6}$

A large nonmarket activity value and/or a high worker bargaining weight generate firm surpluses small enough to match our calibration targets. However, whereas under a high value of nonmarket activity a moderate rise in the minimum increases aggregate welfare even if the bargaining weight is high, when the nonmarket value is low, aggregate welfare is reduced. The reason is that, although a rise in the minimum always generates efficient rationing in the sense that it destroys the matches with the lowest surplus, only high nonmarket values imply near zero match surpluses for the least productive matches; welfare loss from priced out workers is negligible. In contrast, high bargaining weights also imply low firm surpluses, but they do not imply low

generates compositional changes in the labor force that offset each other and mute significant aggregate employment changes has been explored previously with the analysis focusing on minimum wage workers at the margin of the labor force. See Neumark and Wascher (1995); Ahn et al. (2011); and Giuliano (2013) who analyze how an increase in the minimum shifts the labor supply from teenagers with low reservation values to teenagers with high reservation values.

${ }^{5}$ See Wesscls (2005), Neumark and Nizalova (2007), and Neumark et al. (2014) for negative effects on teenage participation and employment.

${ }^{6}$ See Hagcdorn and Manovskii (2008), Costain and Reitcr (2008), Pissarides (2009), and Ljungqvist and Sargent (2017). 
match surpluses if the nonmarket value is low; a higher minimum destroys matches of significant welfare value.

In this way, our results elaborate on the standard welfare analysis based on the Hosios (1990) criterion. First, worker heterogeneity introduces a new dimension to the analysis; welfare equality. The minimum wage does not only affect aggregate welfare, but also welfare differences among workers. Our calibration shows that although the policy widens the welfare gap between the most and least productive, it could still have positive effects on aggregate. Second, unlike the representative worker case, efficiency is not only determined by the bargaining weight's relation to the elasticity of matching. Nonmarket activity is a stronger determinant of the aggregate welfare implications.

Our results have important implications for a minimum wage implementation and evaluation. An optimal implementation would require consideration of the variation in worker bargaining strength across regions and industries of the kind suggested by recent studies on labor market concentration. ${ }^{7} \mathrm{~A}$ thorough evaluation of the policy would call for a serious reflection on what constitutes the value of nonmarket activity of low-wage workers. If teenage employment has low social value compared to that of older workers, in the sense that teenagers might be near indifferent between market and nonmarket participation, a higher minimum could have aggregate welfare improvements. Furthermore, if the policy's goal is poverty reduction and increasing the welfare of low-income households, additional socioeconomic dimensions must be incorporated. The rather dire prediction of our model that a marginal improvement for the highest skilled comes at the expense of the employment and participation of the least skilled, takes a new tone when the identities of these groups are revealed. It is low-education prime-aged workers who benefit from the minimum, and it is their welfare, not the welfare of teenagers, that is more likely to impact low-income households. These considerations must be integrated into the analysis if the policy is to be evaluated beyond its impact on employment and wages.

The paper is organized as follows. Section 2 briefly reviews the related literature. Section 3 presents and analyzes the model. Section 4 describes the estimation procedure of the impact of a higher minimum on different labor market outcomes and discusses its results. Section 5 presents the model's calibration and the counterfactual exercises. Finally, Section 6 concludes. Tables and derivations are included in the Appendix.

\footnotetext{
${ }^{7}$ See Azar et al. (2017),Azar ct al. (2018), Benmelech et al. (2018), Krueger (2018), and Krueger and Posner (2018).
} 


\section{Related Literature}

This paper relates primarily to the search and matching literature on minimum wages. Flinn (2006) presents a general equilibrium model to examine the welfare implications of the minimum wage. He investigates whether the minimum wage can be welfare-improving given the Hosios (1990) criterion for efficiency, and using 1996 data finds that the worker's bargaining weight is too high for the minimum to have positive aggregate welfare consequences. The present paper refines the welfare analysis by introducing intra-labor force welfare disparities, which can be enhanced or reduced by an increase in the minimum depending on the bargaining weight parameter and the nonmarket activity value.

There is a growing literature emphasizing the minimum wage's potential to enhance or reduce inequalities between low-skilled workers. Flinn and Mullins (2015) present a search model with ex ante worker heterogeneity to analyze how schooling decisions could attenuate the detrimental effects of a higher minimum by allowing workers to increase their human capital and escape unemployment. The authors note that, although a higher minimum promotes schooling investment and leads to welfare and efficiency gains, it might have undesirable welfare inequality consequences. When the minimum rises, the lowest skilled are disproportionately affected as previously acceptable matches become unavailable, which translates into longer unemployment periods. Along the same lines, Flinn et al. (2017) investigate on-the-job (OTJ) human capital investment. When workers and firms are given the opportunity to invest in general and specific human capital, it is possible to upgrade an existing match that would have been priced out by a higher minimum otherwise, which dampens the welfare losses of the policy. Here too, a rise in the minimum has differentiated effects on workers; the welfare losses are disproportionately concentrated on the low end of the skill distribution. Flinn et al. (2017) investigate how a wage floor affects the firm's decision to bargain or post wages. They note that, although a rise in the minimum would increase unemployment duration for all workers, its impact on wages could be asymmetric; a pay rise for workers at the low end of the skill distribution at the expense of the wages of those at the top. Engbom and Moser (2017) prosent a search model to link the reduction in earnings inequality in Brazil to the minimum wage. In their model, the firms' competition for workers that follows a hike in the minimum creates a wage ripple effect that fades towards the top of the wage distribution and thus reduces the wage differentials across worker skill types. In our model, a higher minimum also has the potential to reduce the pay differential across worker types provided the firm surplus is 
high enough, which might be the case for the Brazilian labor market.

The present paper follows in the vein of Ahn et al. (2011), who explore the notion that underlying the absence of strong employment effects, a higher minimum produces important changes in the composition of the labor force. They present a search model with a distribution of reservation wages to allow for participation effects, so that a rise in the minimum can persuade, by generating positive search surpluses, or dissuade, through congestion, a particular worker from participating in the market. Our model improves upon this setting in two important ways. First, endogenous search intensity allows labor force participation in an extensive and intensive margin. This way, workers differ not only in their decision to participate, but also in their job-finding efforts, which generates a distribution of participation and employment rates within the same labor market, in line with the empirical variation in outcomes among workers in low-wage occupations. Second, we model heterogeneity as productivity differences that determine all of the worker's market outcomes, which creates a positive correlation between wages, employment rates, and labor force participation, a correlation supported by the data but absent in Ahn et al. (2011). ${ }^{8}$

Other notable studies of minimum wages in a Mortensen-Pissarides environment are Rocheteau and Tasci (2008), and Gorry (2013). As a whole, the search and matching literature describes the complexity of the distortions that a minimum wage generates. The effects of the policy, both on aggregate and at an individual level, are non-monotonic and crucially depend on the prevalent wage setting environment. Moreover, the most interesting distortions seem to occur within the low-wage labor force and imply a trade-off between the welfare of the least skilled and the welfare of the most skilled. Our model incorporates many of these ideas and offers an intuitive and cohesive explanation of the myriad aspects of the policy introduced by previous works. It is also versatile enough to accommodate many phenomena documented by the empirical literature such as labor-labor substitution, under utilization of minimum wages, and wage ripple effects. It even offers a framework to reconcile the seemingly contradicting findings of employment gains and losses after a rise in the minimum, which has sparked a large debate in the empirical literature.

This paper also relates to the vast literature quantifying the effect of min-

\footnotetext{
${ }^{8}$ In their model, there is no link between the identity of those affected by a change in the minimum wage and their market outcomes, so a higher minimum wage could discourage workers with earnings considerably above the minimum. In our model this is not the case; workers with lower wages are the likeliest to leave the labor force as a result of a minimum hike, and workers with higher wages are the likeliest to increase their participation and employment.
} 
imum wages on different labor market outcomes. Consistent with many previous works summarized in Neumark and Wascher (2007), the present study finds statistically significant disemployment for the least skilled teenagers. ${ }^{9}$ Unlike many previous studies, we document a statistically significant, albeit small, positive employment effect for low-education prime-age workers. This finding is, to the best of our knowledge, new in the literature, and we attribute it to our age-education disaggregation, which allows sharper focus on workers affected by the policy.

From a macroeconomic perspective, labor force participation is an outcome of interest on a par with employment; however, its relation with minimum wages remains underresearched. Previous studies on the subject, such as Kaitz (1970), Mincer (1976), Ragan (1977), and Wessels (1980), find that the minimum wage decreased or left unchanged the labor force participation of low-wage workers. Using more recent econometric techniques, and in line with our own results, Wessels (2005) shows that minimum wage hikes have a small but statistically significant negative effect on teenage labor force participation. To the best of our knowledge, the present study is the first one to document a positive participation effect for prime-age workers.

The asymmetric employment effects we find are consistent with other works documenting substitution effects in response to a higher minimum wage. For example, Neumark and Wascher (1995) conclude that a rise in the minimum increases the employment of teenagers with high reservation values. Giuliano (2013) finds a similar compositional effect; it induces the participation of more affluent teenagers at the expense of low-income ones. Other related studies are Teulings (2000), Luttmer (2007), Fairris and Bujanda (2008), and Phelan (2014).

Recently, Cengiz et al. (2018) document no overall reduction in low-wage jobs resulting from a minimum wage hike and, using age-education disaggregation similar to ours, tests for labor-labor substitution across demographics. Contrary to the evidence from previous studies, the authors state that although the bite of the policy varies considerably among the many demographics, it does not appear to have a significant effect on the number of jobs in any of them, which does not support the idea of low-wage demographic substitution after an increase in the minimum wage. ${ }^{10}$

\footnotetext{
${ }^{9}$ These authors broadly review the literature on the employment effect of the policy and report that the majority of studies give a consistent indication of a negative impact, including those that, according to them, provide the most credible evidence. Most studies also show that the disemployment is heavily concentrated in teenagers and other workers in low-wage occupations.

${ }^{10}$ The divergence in findings might be due to their novel estimation method, which com-
} 


\section{The model}

The model follows Pissarides (2000) Chapter Five, adding a fixed distribution of worker productivities. Time is continuous. All agents are risk neutral and discount utility flows at rate $r$. There are $n$ types of workers with fixed productivities $0<y_{1}<\ldots<y_{n}<\infty$. Worker population is defined by $p_{1}, \ldots, p_{n}$, where $p_{i}$ is the share of workers with productivity $y_{i}$, hereinafter type- $i$ workers, and $\sum p_{i}=1$. There is a continuum of identical firms, so the product of a worker-firm match depends entirely on the worker's type and it is equal to $y_{i}$. Employed workers receive a wage $w_{i} \leq y_{i}$. Non-employed workers get a flow nonmarket utility $b<y_{1}$, which includes unemployment benefits and the utility workers derive from leisure. ${ }^{11}$

It is important to remark that we aim to describe heterogeneity in low-wage accupations, so we assume that, although workers differ in their productivity, they are similar enough to participate in the same labor market. Therefore, search is undirected; firms can be matched with any type of worker. ${ }^{12}$ Productivity is perfectly observable by firms and workers, so a type- $i$ worker is hired upon meeting with an endogenous probability $\Pi_{i}$.

Only unemployed workers are allowed to search for a job. ${ }^{13}$ They optimally

pares the pre and post policy wage distribution in a difference-in-difference fashion. It might also be attributed to the specific sample of minimum-wage hike events used, 138 out of 516 from 1976 to 2016. This is an interesting working paper since its findings not only fail to support the labor-labor substitution documented in the literature, but they also contrast sharply with those in Jardim et al. (2017), who used a similar estimation approach to identify the employment effects of the 2015 Seattle minimum wage increase, and found that it had a significant negative impact.

${ }^{11}$ Other models such as Flinn (2006) assume heterogeneity in nonmarket values, so that the minimum wage can have positive participation effects. Our model could feature heterogeneity in nonmarket values. Its mechanics would remain intact as long as the distribution of $b_{i}$ preserved the perfect correlation between $y_{i}$ and the surplus of a match, for example, $b_{i}=a y_{i}$ for $a<1$. However, the welfare predictions of the model would strongly depend on the distribution of fundamental surpluses $y_{i}-b_{i}$. Since the main determinant of the policy's welfare implications is the distribution of fundamental surpluses, $y_{i}-b_{i}$, and not the distribution of $y_{i}$ or $b_{i}$ by themselves, we consider variation only on productivity for simplicity, and because little is known about nonmarket value variation across demographics.

${ }^{12}$ Accmoglu (1999) makes a case for undirected search by pointing out that skill is imperfectly correlated with observable characteristics, such as years of education and age, making it difficult for employers to recruit workers with a particular skill level. Dolado et al. (2009), and Chassamboulli (2011) feature undirected search to introduce skill mismatch. Other models with undirected search include Shimer and Smith (2001), Prics (2008), and Laló (2018).

${ }^{13}$ For simplicity, it is assumed that the match product depends entirely on the worker's fixed productivity, so no incentive for OTJ search exists. The model's predictions would be 
choose a search intensity level denoted by $s_{i}$, which according to Pissarides (2000) can be interpreted as the fraction of unemployed workers who search during a small interval of time, i.e., a labor force participation rate. If $s_{i}=0$, the worker is out of the labor force. Searching has a flow cost $c\left(s_{i}\right)$, where $c^{\prime}\left(s_{i}\right)>0, c^{\prime \prime}\left(s_{i}\right)>0, c(0)=c^{\prime}(0)=0$, and $c(\infty)=\infty$. Similarly, a firm with a vacant job must incur a flow cost $\gamma$.

Unemployment rates are denoted by $u_{i}$; therefore, the fraction of unemployed type- $i$ workers in the aggregate unemployed population, $\mu_{i}$, is given by

$$
\mu_{i}=\frac{p_{i} s_{i} u_{i}}{\sum p_{j} s_{j} u_{j}}
$$

where $\sum p_{j} s_{j} u_{j}$ is the measure of all unemployed workers searching for a job. Labor market tightness is defined as

$$
\theta \equiv \frac{v}{\sum p_{j} s_{j} u_{j}},
$$

where $v$ is the number of vacancies as a fraction of the worker population. The number of matches made per-unit of time is given by the CRS matching function $h\left(\sum p_{j} s_{j} u_{j}, v\right)$, differentiable and increasing in both arguments. The workers' matching rate is denoted by $f(\theta) \equiv h\left(\sum p_{j} s_{j} u_{j}, v\right) / \sum p_{j} s_{j} u_{j}=h(1, \theta)$. Similarly, a firm's matching rate is given by $q(\theta) \equiv h\left(\sum p_{j} s_{j} u_{j}, v\right) / v=$ $h\left(\theta^{-1}, 1\right)$. Unemployed workers are matched faster in a tighter market, that is, when there are more vacancies relative to job seekers. Similarly, firms are matched with workers faster when there are more unemployed workers relative to vacancies. Matches are terminated at an exogenous Poisson rate $\delta$.

broadly robust to adding match-specific heterogeneity as in Flinn et al. (2017) since more productive workers would still receive higher wages in expectation, and therefore would have higher participation and employment rates. In such an environment, not all workers forced into unemployment by a higher minimum would exit the labor force, since they could still be hirable by some firms. However, it would still be true that those priced-out would be the lowest skilled, so a higher minimum would still increase average productivity and potentially tighten the market. Although the basic mechanism of the model would remain unchanged, the results of the welfare experiments performed using the calibrated model could be drastically different given that OTJ search models prescribe a lower worker bargaining weight, a parameter which greatly determines the outcomes of the exercises. Also, incorporating OTJ search to a general equilibrium model is not a trivial matter. This is the subject of future research. 


\subsection{Worker Behavior}

At the steady state, the lifetime expected utility of a type- $i$ worker, $E_{i}$, obeys the flow Bellman equation

$$
r E_{i}=w_{i}+\delta\left(U_{i}-E_{i}\right),
$$

where $U_{i}$ is the lifetime expected utility of a type- $i$ unemployed worker and satisfies

$$
r U_{i}=\max _{s_{i} \geq 0}\left\{b-c\left(s_{i}\right)+s_{i} \Pi_{i} f(\theta)\left[E_{i}-U_{i}\right]\right\},
$$

where $s_{i} \Pi_{i} f(\theta)$ is the unemployment-exit rate. Workers set their search intensity to maximize $r U_{i}$ taking $\theta$ and the rest of the parameters as given. The optimal choice of search intensity solves

$$
c^{\prime}\left(s_{i}\right)=\Pi_{i} f(\theta)\left[E_{i}-U_{i}\right] .
$$

The restrictions on $c\left(s_{i}\right)$ guarantee a unique solution to (4). All else equal, workers increase their optimal participation/search efforts when the market tightens, since the job finding rate improves and their match surplus increases. Similarly, a reduction in market tightness has a discouraging effect on workers; in a slacker market the marginal benefit of a search unit is reduced, which lowers the optimal search level. Lemma 1 in Appendix A provides proof of this.

\subsection{Firm Behavior}

The present discounted value of expected profits from a vacant job, $V$, at the steady state satisfies the Bellman equation

$$
r V=-\gamma+q(\theta)\left[\sum_{i} \Pi_{i} \mu_{i}\left(J_{i}-V\right)\right]
$$

where $J_{i}$ is the firm's expected return from a vacancy filled by a type- $i$ worker. Equation (5) states that the capital cost of an open vacancy has to be exactly equal to the rate of return of the vacancy, i.e., the flow costs of recruiting plus the expected capital gain. The asset value of an occupied vacancy by a type- $i$ worker satisfies a similar Bellman equation: 


$$
r J_{i}=y_{i}-w_{i}+\delta\left(V-J_{i}\right)
$$

The capital gain of a filled vacancy is equal to the income flow, $y_{i}-w_{i}$, plus the expected capital loss when the match is exogenously destroyed. Taking market tightness as given, each firm sets $\Pi_{i}$ in order to maximize its expected profits. The best response function of a firm satisfies the following rule: $\Pi_{i}=1$ if $J_{i}-V \geq 0$, and $\Pi_{i}=0$ if $J_{i}-V<0$. That is, if the firm's surplus of a match is strictly positive, the firm will always hire the worker. If it is zero, the firm is indifferent between hiring and continuing to search for a worker given the incurred search costs. Without loss of generality, I assume that firms hire the worker in such an instance. If the surplus is strictly negative, the worker is never hired. Wages are determined through Nash-bargaining subject to a minimum wage, $m$, with full compliance. This way, the wage of a type- $i$ worker solves:

$$
w_{i}=\arg \max \left(E_{i}-U_{i}\right)^{\beta}\left(J_{i}-V\right)^{1-\beta} \quad \text { s.t. } \quad w_{i} \geq m,
$$

where $\beta$ is the worker's bargaining weight.

\subsection{Steady-State Equilibrium}

The firm's free-entry condition implies that the value of a vacancy is zero, $V=0$. This way, the optimal hiring response for firms follows:

$$
\Pi_{i}^{*}= \begin{cases}1, & y_{i} \geq m \\ 0, & y_{i}<m .\end{cases}
$$

Workers with productivities at least as high as the minimum wage will always be hired, so the solution to (7) can be expressed as:

$$
w_{i}^{*}=\max \left\{m, w_{i}^{N}(\theta)\right\}, \quad y_{i} \geq m,
$$

where $w_{i}^{N}(\theta)$ is the unconstrained Nash-bargaining wage. Lemma 2 in Appendix A shows that in equilibrium, the unconstrained wage is increasing in market tightness such that $\lim _{\theta \rightarrow \infty} w_{i}^{*}=y_{i}$. That is, at the limit, the worker takes the whole output of the match. Using (4) and (8), the optimal search rule is derived. 


$$
s_{i}^{*}=\left\{\begin{array}{llll}
s_{i} & \text { s.t. } & c^{\prime}\left(s_{i}\right)=f(\theta)\left[E_{i}-U_{i}\right] & y_{i} \geq m, \\
0 & & y_{i}<m .
\end{array},\right.
$$

It states that workers with productivites lower than the minimum will optimally choose a search intensity of zero; they will exit the labor force. For those workers with a productivity equal or higher than the minimum, search intensity is proportional to their match surplus, which is increasing with productivity; more productive workers participate more. In the presence of a minimum wage, workers with different productivities could receive the same wage $m$. In such instance, their optimal choice of search intensity would be equal. This way we can establish that $s_{1} \leq s_{2} \leq, \ldots, \leq s_{n}$, i.e., equilibrium search intensity is non-decreasing in productivity.

At the steady state, the flows into and out of unemployment must be equal for every worker type. That is, $p_{i}\left[1-u_{i}\right] \delta=s_{i} \Pi_{i} f(\theta) p_{i} u_{i}$. Solving for $u_{i}$, a Beveridge curve for type- $i$ worker can be derived:

$$
u_{i}=\frac{\delta}{\delta+s_{i} \Pi_{i} f(\theta)}
$$

This is the equilibrium unemployment rate. Equilibrium search intensity implies that $u_{1} \geq u_{2} \geq, \ldots, \geq u_{n}$; workers with higher productivities have lower unemployment rates. With the free entry condition and combining equations (5) and (6), the vacancy supply condition (VSC) is derived:

$$
\sum_{i} \Pi_{i} \mu_{i}\left[y_{i}-w_{i}\right]=(r+\delta) \frac{\gamma}{q(\theta)}
$$

As noted in Pissarides (2000), the restrictions on the matching function and the fact that intensity enters the matching process multiplicatively, guarantee that (12) uniquely determines equilibrium market tightness. A steady-state equilibrium of the model is defined as follows:

Definition 1: A steady-state equilibrium consists of a collection of values $\left\{s_{i}, \prod_{i}, w_{i}, u_{i}\right\}_{i=1}^{n}$, and $\theta$, satisfying (10),(8), (9), (11), and (12).

At an equilibrium, type- $i$ workers are classified as non-hirable if $y_{i}<m$, or as hirable if $y_{i} \geq m$. It can be shown that for non-hirable workers: $\Pi_{i}=0$, $s_{i}=0$, and $u_{i}=1$. Given the constraint of the minimum, non-hirable workers would generate a negative match surplus for the firm, so no firm hires them. Knowing this, workers optimally choose not to participate in the market since 
it is a costly activity; non-hirable workers exit the labor force. This is the "trim" effect that leaves any worker with a productivity below $m$ out of the market; the higher the minimum, the larger the share of the population out of the labor force.

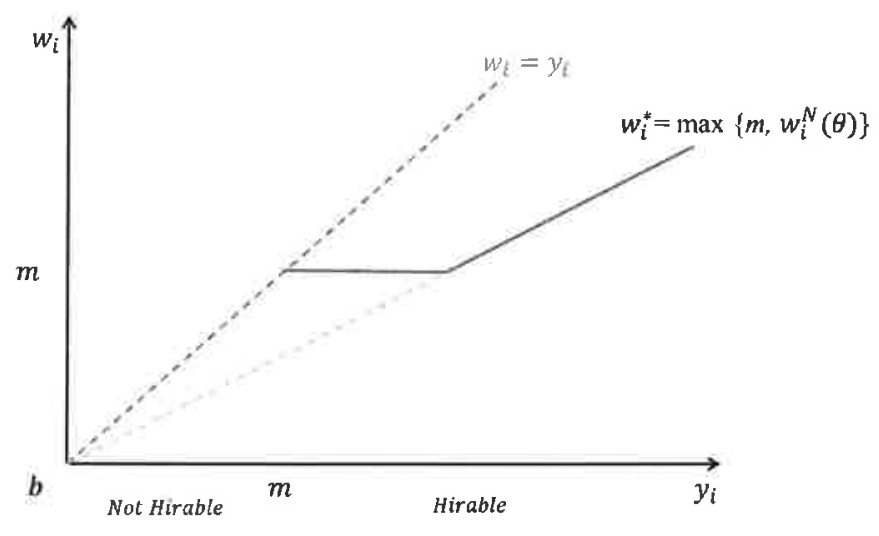

Figure 1: Equilibrium wage schedule

Hirable workers are productive enough to generate positive firm surplus, and thus will always be hired upon meeting; $\Pi_{i}=1$. For them, wages, search intensity, and employment, are increasing and continuous functions of productivity. This generates a diversity of market outcomes. Figure 1 illustrates the equilibrium wage schedule. For some hirable workers the minimum wage is binding, that is, $m \geq w_{i}^{N}(\theta)$. All these workers receive the same wage $m$, and thus have the same labor force participation and employment rate. Other more productive workers, for which the minimum is not binding, $m<w_{i}^{N}(\theta)$, receive the unconstrained Nash-bargaining wage, which, along with their participation and employment, strictly increases with productivity.

\subsection{Changes in the minimum wage.}

Our main results come from the comparative statics of the model with respect to the minimum wage. From the VSC (12), one can observe that the impact of a higher minimum on equilibrium market tightness is ambiguous. The lefthand side of the VSC is a weighted average of the of firm's possible income flows across workers. Although firms have the option not to hire a worker if, given a new minimum, their associated firm surplus is negative, a rise in the minimum reduces the firm surplus from matches that are productive enough to still 
generate a positive firm surplus, but not productive enough to not be bound by the policy. This lowers the expected profit and discourages vacancy creation. On the other hand, the incentives for vacancy creation of a higher minimum come through changes in $\mu_{i}$, which determines the productivity composition of the unemployed. As a rising minimum trims workers off, the denominator in (1) decreases. So, hirable workers, who are the most productive, increase their representation in the pool of the unemployed, and therefore rise the expected profit of an open vacancy. ${ }^{14}$

Which effect dominates depends on the parameter values and the skill distribution. Proposition 1 summarizes the effects that a higher minimum could have on workers depending on its impact on market tightness.

Proposition 1 : Let $\theta$ and $\theta^{\prime}$ be the equilibrium market tightness under $m$ and $m^{\prime}$ respectively, where $m<m^{\prime}$. Consider an increase from $m$ to $m^{\prime}$ :

1. Workers such that, $m \leq y_{j}<m^{\prime}$, are driven out of the labor force.

2. If $\theta \leq \theta^{\prime}$, all hirable workers, i.e. those such that $y_{i} \geq m^{\prime}$, experience an increase in employment, labor force participation, and wages.

3. If $\theta>\theta^{\prime}$, the most productive hirable workers, those such that $m^{\prime} \leq$ $w_{i}^{N}(\theta)$, experience an employment, participation, and wage reduction. The least productive hirable workers, those such that $m^{\prime}>w_{i}^{N}(\theta)$ experience a wage rise, and could increase their participation and employment.

\section{Proof: Appendix A}

The proposition shows how a rise in the minimum has an asymmetric impact on individual outcomes. Regardless of the effect on tightness, workers such that $m \leq y_{i}<m^{\prime}$ experience total employment reduction and exit the labor force. How a higher minimum affects still hirable workers depends on its effect on market tightness. Figure 2 shows the two possible scenarios. Panel a) depicts an increase in market tightness after a hike in the minimum; a situation with strong, in fact diametrically opposed, asymmetries between hirable and non-hirable workers. A tighter market increases the job finding rate, which increases the effective bargaining power of workers. This moves the unconstrained Nash-bargaining wage curve closer to the 45 degree line.

\footnotetext{
14 See Rocheteau and Tasci (2008) for a comprehensive analysis of the impact that a higher minimum could have when endogenous search intensity is present for the case of a representative worker.
} 
With better market conditions, workers increase their search efforts, and consequently, their employment and participation. The upward shift of the wage schedule is consistent with a situation known in the literature as underutilization of the minimum wage.

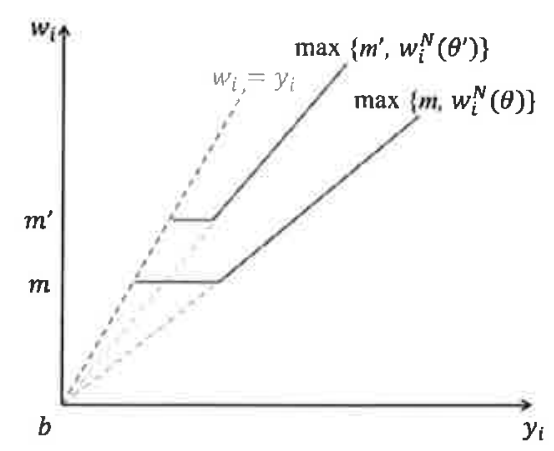

a) $\theta<\theta^{\prime}$

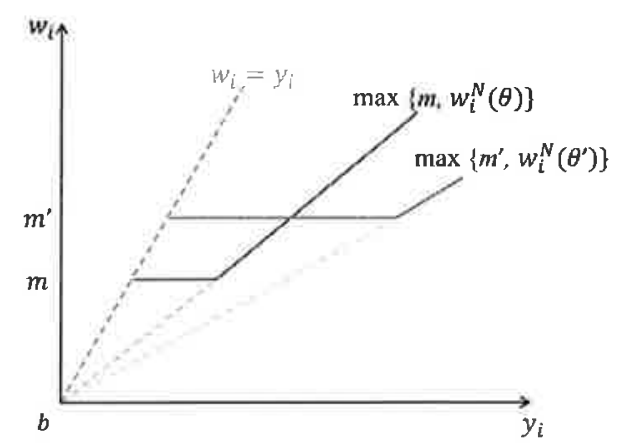

b) $\theta>\theta^{\prime}$

Figure 2: An increase in the minimum wage

Falk et al. (2006) raise the following question: why do profit-maximizing employers pay above the new minimum to those workers who earned less than this new level before its introduction? This question follows from the evidence reporting low utilization of minimum wages in situations where, in principle, employers could pay the minimum or less. ${ }^{15}$ Using data from a laboratory experiment, these authors argue that the introduction of a minimum wage increases the wage workers perceive as fair, which forces firms to pay wages above a new minimum even when workers were earning less originally. In our model, the upward shift of the wage schedule that results from a tightening of the market, changes the coverage of the policy in terms of the types of workers bound by it. So after its implementation, a worker who should be receiving the new minimum, had market tightness remained constant, is now paid above it due to the stronger bargaining position that comes with a tighter market.

A higher minimum could also reduce market tightness. Panel b) depicts the situation. In this case, the effective bargaining power of workers has weak-

\footnotetext{
${ }^{15}$ Studies such as Frecman et al. (1981), Katz and Krucger (1992), Dickens and Manning (2004), and Dube et al. (2015) show that this practice is common. For example, Katz and Krueger (1992) report that some fast-food restaurant managers were not using the subminimum wage option because they believed that it would not attract qualified teenage workers at that wage.
} 
ened, so the unconstrained Nash-Bargaining wage line rotates downward. This is a curious situation where the least productive hirable workers, those such that, $m^{\prime}>w_{i}^{N}(\theta)$, increase their wage at the same time that the wages of the most productive hirable workers, those that $m^{\prime} \leq w_{i}^{N}(\theta)$, decreases. Employment and participation rates would drop in a slacker market, other things being equal. However, the wage "bump" for those workers bound by the new minimum could be significant enough to incentivize their search efforts and increase their job finding rate. In this case, their employment and participation rates would increase even in a slacker market.

To summarize, if a higher minimum tightens the market, it increases the employment, participation, and wages of the workers that remain hirable, which enhances the welfare differences between hirable and non-hirable workers. If the market slackens, the differences in market outcomes among the hirable workers are reduced; the minium wage has an equalizing effect in terms of welfare. Unfortunately, no general insightful conditions can be obtained analytically to characterize how tightness will respond to a change in the minimum wage.

\subsection{Bargaining Weights and Nonmarket Activity}

There are two parameters that play a crucial role in whether a rise in the minimum tightens the market; the worker's bargaining weight, $\beta$, and the value of nonmarket activity, $b$. To understand their role, we analyze how they determine the relative strength of each of the two opposing effects that a higher minimum has on vacancy creation. Using the Nash-bargaining wage solution, the VSC (12) can be expressed as

$$
\sum_{m<y_{j} \leq \bar{y}} \Pi_{j} \mu_{j}\left[y_{j}-m\right]+\sum_{\bar{y}<y_{i}} \Pi_{i} \mu_{i} \frac{\left[y_{j}-b+c\left(s_{i}\right)\right](1-\beta)(r+\delta)}{r+\delta+\beta s_{i} \Pi_{i} f(\theta)}=(r+\delta) \frac{\gamma}{q(\theta)}
$$

where $\bar{y}$ is the productivity level such that the unconstrained Nash-bargaining wage is equal to the minimum, and is given by

$$
\bar{y}=m \frac{r+\delta+\beta s_{i} \Pi_{i} f(\theta)}{\beta\left(r+\delta+s_{i} \Pi_{i} f(\theta)\right)}-[b-c(s)] \frac{(1-\beta)(r+\delta)}{\beta\left(r+\delta+s_{i} \Pi_{i} f(\theta)\right)} .
$$


The threshold $\bar{y}$ determines the coverage of the minimum wage. For all workers with productivities $m<y_{j} \leq \bar{y}$, the minimum is binding, and all those such that $\bar{y}<y_{i}$, receive the unconstrained bargaining wage. The positive effect on vacancy creation of a higher minimum is the "trim" of the labor force. It induces changes in the composition of the unemployment pool. These compositional changes are captured by the terms $\mu_{i}$ 's, which depend on $m$ through (10). $\mu_{i}$ is non-decreasing in $m$ for all workers that remain hirable, so as $m$ increases, these workers, who are also the most productive, increase their representativity, which raises the expected quality of a match. In isolation, this would increase the left hand side of (13) for all values of $\theta$, raising the equilibrium market tightness. The negative effect is the "bump" on wages, captured by the first summation on the left side of (13). As $m$ increases, the terms $y_{j}-m$ shrink, and the left hand side of (13) is reduced for all values of $\theta$. Combined, the two effects make the impact on equilibrium market tightness ambiguous. However, the relative strength of each is determined by parameters $\beta$ and $b$. Using (14), one could show that as either of these parameters increases, the "bump" effect diminishes as the first summation on the left side of (13) includes fewer elements.

The reason is that higher values of $\beta$ or $b$ increase unconstrained wages $w_{i}^{N}(\theta)$, lowering the coverage of the minimum and therefore its direct impact on labor costs. At the limit, as $w_{i}^{N}(\theta) \rightarrow y_{i}$, a rise in the minimum wage only eliminates the least productive matches, without directly increasing wages for the rest of workers; a pure "trim" effect. On the other hand, low values of $\beta$ and $b$ reduce unconstrained wages, which increases the coverage of the minimum wage. In this case, increments in $m$ produce a wage "bump" for many workers, which would stifle the incentive for vacancy creation from gains in average worker productivity.

To summarize, the impact of the minimum on market tightness depends on the wedge between productivity and unconstrained wages. A small wedge implies low coverage of the policy, and therefore, a weaker negative impact on vacancy creation. Next, we analyze how the bargaining weight and the nonmarket value affect the aggregate welfare implications of the policy.

\subsubsection{Welfare Implications of $\beta$}

$\beta$ has long been recognized in the literature as a key determinant of the welfare impact of the policy. The well-known Hosios (1990) condition states that in a search and matching environment, efficiency can be achieved by setting the minimum wage at the level of the Nash-Bargaining wage that would be reached 
if the workers' bargaining weight parameter were equal to their share in the matching process. This result provides a clear criterion for the desirability of the policy in terms of welfare. However, the condition is formulated under a representative-worker assumption, so it may not hold when workers vary in their productivity, since the optimal minimum wage prescribed for a particular worker could be too high for less productive workers, and too low for more productive ones. ${ }^{16}$

In the present model, it is not possible to derive a clear criterion for optimality. However, it is easy to see that, for a given value of nonmarket activity, the minimum wage still has a non-monotonic effect on welfare, depending on the bargaining weight. As $\beta$ approaches zero, from equation (4), the optimal search effort approaches zero, along with the employment and participation of all types of workers. In this situation, the presence of a minimum clearly would be welfare enhancing as it would encourage worker participation. The minimum wage could also be so high that it discourages the participation of most workers and severely hampers vacancy creation for those that remain in the market. In this case, a reduction of the minimum would be beneficial. A novel insight is that, in the presence of worker heterogeneity, the bargaining parameter not only affects the aggregate welfare implications, but it also determines whether a higher minimum enhances or reduces welfare inequalities within the labor force.

If the worker's bargaining weight is low, the minimum is not only welfareenhancing in aggregate, but could promote welfare equality, as it makes it more likely that a rise in the minimum slackens the market. In contrast, if the parameter is high, a rising minimum reduces aggregate welfare and would widen the welfare gap between the most and least productive workers, since the market would most likely tighten.

\subsubsection{Welfare Implications of $b$}

The nonmarket value of workers also plays a crucial role in the welfare impact of the policy. Although it is only the relation between $y_{i}$ and $m$ that determines the measure of workers priced out by the policy, it is $b$ that determines the cost of this trimming in terms of welfare. Our measure of social welfare is the steady-state sum of all agents' utilities, which can be expressed as the sum of

\footnotetext{
${ }^{16}$ This observation has been made by Flinn and Mullins (2015). They note that in the presence of heterogeneity, there is a "Hosios-like" condition in the sense that the welfare improvements are smaller for high values of the bargaining weight. This is true in our model too.
} 
fundamental surpluses net of search and recruiting costs

$$
\sum p_{i}\left(1-u_{i}\right)\left(y_{i}-b\right)+b-\sum p_{i} u_{i} c\left(s_{i}\right)-\theta\left[\sum p_{i} s_{i} u_{i}\right] \gamma
$$

The Nash bargaining weight affects our measure of welfare only through its impact on equilibrium market tightness. However, $b$ does not only affect equilibrium market tightness, but also determines the match fundamental surplus $y_{i}-b$ (Ljungqvist and Sargent (2017)). Heterogeneity in worker productivity generates a distribution of match surpluses even when $b$ is common across workers. This means that the rise in the minimum is always efficient in the sense described in Lee and Saez (2012); it destroys the matches with the lowest surplus first.

The primary impact of a higher minimum on welfare is the elimination of the lowest surplus matches and, if the minimum tightens the market, the creation of higher surplus ones. For the market to tighten after a hike in the minimum, the wedge between unconstrained wages and productivity must be sufficiently narrow. Either a high value of $\beta$ or $b$ would achieve this. However, only when $b$ is high, the cost of a higher minimum in terms of fundamental surpluses is low. If $b$ is close to the productivities of the least productive workers, the minimum wage destroys matches with almost zero welfare value in favor of matches with more significant contributions to welfare. On the other hand, if $b$ is relatively low even for the least productive workers, the minimum could be destroying matches of considerable match surplus, which would have a large negative impact on welfare.

In the presence of worker heterogeneity, two main observations regarding the welfare impact of the policy can be made. First, a rise in the minimum could enhance or mitigate welfare inequalities within the labor force. Second, the impact of the policy on aggregate welfare and within-labor force welfare equality does not only depend on the worker's bargaining weight parameter, but also, and to a large extent, on the value of nonmarket activity. In practice, even if the wedge between wages and productivity could be perfectly observed, it would be difficult to disentangle and quantify the contributions of $\beta$ and $b$ separately, which complicates the welfare analysis policy.

\section{Empirical Analysis}

Without information on the wedge between the workers' marginal productivities and their unconstrained wages, it is not possible to conjecture on the 
impact of the minimum wage. Depending on these unknowns, our model in Section 3 could accommodate many different scenarios. If the market tightens as the result of a higher minimum, more productive workers should increase their employment and market participation at the expense of the employment and participation of the least productive. If the market slackens, lower employment and participation rates should be expected for all workers. A higher minimum might also leave market tightness unchanged if the hike is not too large relative to the workers' marginal productivities. In this section we investigate whether different workers are affected asymmetrically by an increase in the minimum wage. To do so, we estimate the impact of the policy on employment, labor force participation, and wages, dissaggregating the observations by age and education; two variables often used as proxies for productivity. Differences between the estimated elasticities across demographic groups will be informative of the impact of the policy on market tightness, and therefore of the wedge between productivities and wages.

\subsection{Data and Estimation Strategy}

We compile a repeated cross-sectional sample at an individual level from the Current Population Survey (CPS) basic monthly data, for 1994-2013, which contains detailed individual information such as education, age, labor force status, and hourly earnings. Each observation is merged with a monthly minimum wage variable; the federal or the state minimum, whichever is higher. ${ }^{17}$ Additionally, observations are merged with data on state-level quarterly personal income per capita and monthly population shares for each demographic group. ${ }^{18}$

The most common specification in the empirical literature is the panel difference-in-difference canonical model

$$
y_{i s t}=\alpha+\beta M W_{s t}+\delta Z_{s t}+\lambda X_{i s t}+\gamma_{s}+\tau_{t}+\varepsilon_{i s t},
$$

\footnotetext{
${ }^{17}$ CPS basic monthly data from the NBER wclsite. Thanks to Ian Salas for providing the minimum wage data, which can be downloaded from his wobsite along with many other useful datasets and codes.

${ }^{18}$ Quarterly personal income per capita was constructed using the seasonally adjusted state personal income provided by the BEA and data on state population from the U.S. Consus Burculu. It is standard in the literature studying teenagers and other low-wage occupations to include the overall unemployment rate to control for the business cycle, arguing that the demographic under study is small enough to discard any reverse causality or simultaneity concern. Some of our considered demographics are considerably larger, so to control for business cycles, quarterly personal income per capita is used instead.
} 
where $i, s$, and $t$ denote, respectively, individual, state, and time. The dependent variables, $y_{i s t}$, are a dichotomous employment variable, a dichotomous labor force participation variable, and the natural log of hourly earnings. $M W$ is the $\log$ of the effective minimum wage; $Z$ is a vector of state characteristics that includes quarterly per-capita income and the population share of the demographic of interest. ${ }^{19} X$ is a vector of individual characteristics; race, age, education, marital status, and gender. $\gamma_{s}$ and $\tau_{t}$ denote state and time fixed-effects respectively.

According to Dube et al. (2010), the canonical specification fails to properly control for spatial heterogeneity in trends, and thus it generates biases toward negative elasticities of the dependent variable. To address this issue, Allegretto et al. (2011) propose two additional sets of controls; census division-specific time-effects, which remove the variation across census divisions by controlling for spatial heterogeneity in regional economic shocks, and state-specific linear trends, which capture long-run growth differences across states. The additional controls render the specification

$$
y_{i s t}=\alpha+\beta M W_{s t}+\delta Z_{s t}+\lambda X_{i s t}+\gamma_{s}+\tau_{d t}+\pi_{s} \cdot t+\varepsilon_{i s t},
$$

where $\tau_{d t}$ is the census division-specific time-effect, and $\pi_{s} \cdot t$ represents the state-specific linear time trend. This augmented specification has also come under scrutiny. Arguments have been made that the additional controls preclude the identification of any effect that the policy might have had, sparking a heated debate in the empirical literature. ${ }^{20}$ Given the ongoing debate and the fact that our conclusions will not depend on the particular specification used, there is no preferred specification. Both specifications are estimated with standard errors clustered at the state level to account for the likely serial correlation among observations within the same state. ${ }^{21}$ Additionally to individual observations, we also consider state-level employment and labor force participation rates as our dependent variable for robustness. As Neumark et al. (2014) point out, because the identifying information is the state-level mini-

\footnotetext{
${ }^{19}$ Population shares are included to control for demographic changes that are considered as exogenous, aside from the migration that differences in the minimum wage could induce.

${ }^{20}$ See Neumark et al. (2014), a response from Allegretto et al. (2017), and a subsequent reply by Ncumark and Wascher (2017) for an interesting exchange of ideas. Mcer and West (2015) argue that the inclusion of state-specific time trends will attenuate the estimates of the impact of the minimum wage on the growth of a variable, so even real causal effects on the level of the variable can be attenuated to be statistically indistinguishable from zero.

${ }^{21}$ See Bertrand et al. (2004).
} 
mum wage variation, the use of state-level or individual observations should be inconsequential. Nonetheless, it is possible that including the individual-level controls (sex, race, age, education, and marital status) could lead to some differences in the results. Although the results from individual observations and aggregate rates are very similar, we believe that the inclusion of all these demographic characteristics offers a better control for the heterogeneity across states; thus we prefer the results from individual observations.

\subsection{Results and Theoretical Implications}

Table 1: Minimum Wage Elasticities of Market Outcomes

\begin{tabular}{|c|c|c|c|c|c|c|c|}
\hline & & \multicolumn{2}{|c|}{ Employment } & \multicolumn{2}{|c|}{ LFP } & \multicolumn{2}{|c|}{ Wageg } \\
\hline & & (1) & (2) & (1) & $(2)$ & (1) & (2) \\
\hline \multicolumn{8}{|l|}{ 16-19 (All) } \\
\hline & Individual & -0.092 & -0.091 & $-0.092^{* *}$ & $\begin{array}{c}-0.144^{* *} \\
(0.054)\end{array}$ & $\begin{array}{c}0.172^{* * *} \\
(0.028)\end{array}$ & $\begin{array}{c}0.146^{* * *} \\
(0.029)\end{array}$ \\
\hline \multirow{4}{*}{ 25-44 (All) } & Obs. & \multicolumn{2}{|c|}{1728421} & \multicolumn{2}{|c|}{1728421} & \multirow{2}{*}{\multicolumn{2}{|c|}{154434}} \\
\hline & & & & & & & \\
\hline & \multirow[t]{2}{*}{ Individual } & 0.019 & & 0.008 & 0.014 & -0.002 & 0.029 \\
\hline & & \multicolumn{2}{|c|}{8562131} & \multicolumn{2}{|c|}{8562131} & \multicolumn{2}{|c|}{920322} \\
\hline \multicolumn{8}{|l|}{ LTHS (All) } \\
\hline & Individual & -0.035 & -0.011 & -0.039 & -0.033 & $0.084^{* *}$ & $0.064^{* *}$ \\
\hline \multirow{5}{*}{ HS (All) } & & $(0.048)$ & $(0.027)$ & $(0.026)$ & $(0.024)$ & $(0.037)$ & $(0.028)$ \\
\hline & Obs. & \multicolumn{2}{|c|}{2604614} & \multicolumn{2}{|c|}{2604614} & \multicolumn{2}{|c|}{269657} \\
\hline & Individual & $0.031^{*}$ & $0.024^{*}$ & $0.018^{* *}$ & 0.005 & 0.015 & 0.021 \\
\hline & & $(0.019)$ & $(0.013)$ & $(0.009)$ & $(0.012)$ & $(0.024)$ & $(0.018)$ \\
\hline & Obs. & \multicolumn{2}{|c|}{5777202} & \multicolumn{2}{|c|}{5777202} & \multicolumn{2}{|c|}{762682} \\
\hline \multicolumn{8}{|l|}{ 16-19 (LTHS) } \\
\hline & Individual & $-0.204^{*}$ & $-0.139^{*}$ & $-0.176^{* *}$ & $-0.183^{* *}$ & $0.218^{* * *}$ & $0.173^{* * *}$ \\
\hline \multirow{5}{*}{ 25-44 (HS) } & & $(0.108)$ & $(0.076)$ & $(0.066)$ & $(0.072)$ & $(0.026)$ & $(0.038)$ \\
\hline & Obs. & \multicolumn{2}{|c|}{1097458} & \multicolumn{2}{|c|}{1097458} & \multicolumn{2}{|c|}{81119} \\
\hline & Individual & & $0.054^{* * *}$ & $0.032 * *$ & $0.031^{* *}$ & 0.013 & 0.032 \\
\hline & & $(0.019)$ & $(0.015)$ & $(0.012)$ & $(0.012)$ & $(0.032)$ & $(0.021)$ \\
\hline & Obs. & \multicolumn{2}{|c|}{2693477} & \multicolumn{2}{|c|}{2693477} & \multicolumn{2}{|c|}{362342} \\
\hline
\end{tabular}

Our demographics are 16-19 and 25-44 year olds of all education levels, less than high school (LTHS) and high school (HS) groups of all ages, 16-19 year olds with less than high school, and 25-44 year olds with high school. The dependent variables are a binary for employment, a binary for labor force participation (LFP), and the log of hourly wage. The elasticities for the employment and participation variables are obtained by dividing the regression coefficients by the fraction of employed and participating individuals in the demographic of interest respectively. Standard errors clustered at state level are reported in parentheses. Significance levels are: $* * * 1 \%, * * 5 \%, * 10 \%$. Both specifications include individual controls for age,education, gender, race, marital status, state-level quarterly per-capita income, state-level population share of the demographic of interest, and state-fixed effects. Specification (1) additionally includes time-fixed effects and specification (2) additionally includes census-division specific time-effects, and state-specific linear trends.

We report the estimated minimum wage elasticities of our three market outcomes for various demographics. Observations are divided by age: 16-19, 
20-24, 25-44, and 45-64; and by educational attainment: less than high school (LTHS), high school (HS), some college, college, and advanced education. ${ }^{22}$ This way, we have 9 wide demographic groups using a one-way dissagregation, either by age or by education, and 17 narrower groups under a two-way dissagregation that interacts age and education. ${ }^{23}$ We will refer to the latter as the two-way demographic groups, which are meant to sort workers by productivity more accurately. Sorting by productivity is crucial for the identification of any significant effects of the policy, since failing to do so could place workers affected by a rise in the minimum wage in opposite ways in the same demographic, thus potentially rendering an aggregate effect indistinguishable from zero. Table ?? in the appendix shows market outcomes statistics for the two-way demographics. ${ }^{24}$

One motivation for this paper is the possibility that ignoring worker heterogeneity could cover important compositional changes behind aggregate insignificant effects. To test this, we estimate the elasticities at different levels of disaggregation. First with our whole sample; all ages and education levels, and then for low-education workers only. We further disaggregate by age and by education separately, and then by the interaction of these two variables. Table 1 in the text reports of the most relevant results, and Tables ??, ??, ??, and ?? in the appendix report the full set of results.

Table ?? presents the results for the regressions on all observations. They are statistically indistinguishable from zero; minimum wages do not affect overall labor market outcomes. Considering only low education observations (high school or less) does not change these results. Only our specification controlling for spatial heterogeneity reports a weakly significant elasticity for wages of 0.031 .

As can be observed in Tables ?? and ??, college and advanced education groups, in general, do not display any effect statistically different from zero in any outcome, except for the wages of 20-24 year olds with college education. The lack of statistical significance in high-education groups is not surprising, given their small share of workers earning no more than $10 \%$ above

\footnotetext{
${ }^{22}$ Classifications follow Jaeger (1997) who defines high school attainment as completing the 12 th grade regardless of high school diploma receipt. Advanced schooling is defined as having a master's degree, a professional school degree, or a doctorate degree.

${ }^{23}$ The demographics of 16-19 year olds with college or advanced education, and 20-24 year olds with advanced education are excluded due to the fact that in several state-month observations, these demographics are absent from the sample.

${ }^{24}$ An intuitive way to sort workers would be by their reported wage, however CPS data does not include wage information on non-employed workers, which would be necessary to estimate the impact on employment and labor force participation.
} 
the minimum, as Table ?? shows. For workers with some college, the situation is similar. As a whole, this group shows no statistical significance in any outcome, and the two-way disaggregation shows negative participation effects in the specification controlling for spatial heterogeneity only for both of the youngest demographics.

In contrast, the low-education demographics do display statistically signifcant results. Workers with high school education show a statistically significant elasticity of employment of 0.031 , and 0.024 depending on the specification. Workers with less than high school education present a statistically significant elasticity of wages of around 0.07. Although these results are somewhat informative of the impact of the minimum wage on low-education markets, aggregation at the education level does hide stronger effects on particular age demographics within these groups. Under two-way disaggregation, the elasticities reported in Tables ?? and ?? are mostly not statistically significant except for two demographics. For teenagers (16-19) with less than high school education, the elasticity of employment of -0.139 is statistically significant, and so is the elasticity of labor force participation of $-0.183 .{ }^{25}$ The elasticity of wages is positive, statistically significant, and equal to 0.173 . The other demographic displaying statistically significant effects are prime-age workers, 25-44 year olds, with high school education. The estimated elasticities for employment and labor force participation for this demographic are 0.054 and 0.031 respectively. ${ }^{26}$ The rest of the narrow demographics do not show any statistically significant effects, and the elasticity sign varies significantly from group to group and between specifications. ${ }^{27}$

\footnotetext{
${ }^{25}$ Kaitz (1970), Mincer (1976), Ragan (1977), and Wesscls (1980), estimated the effects of the minimum wage on labor force participation and found that a rise in the minimum decreased (or did not affect) the labor force participation rate of low-wage workers. More recently, Wessels (2005) investigated the effect on teenage participation and concluded that minimum wages decrease teenage labor force participation and their proportion of new entrants into the labor force. The results regarding wages are consistent with Neumark and Wascher (2007) and Allegretto et al. (2011), who also document a statistically positive effect on wages for teenagers. It is also worth mentioning that whether the minimum wage reduces teenage employment is one of the most contentious topics in economics. In accordance with many previous works, we do not find statistically significant results for all teenagers, it is only after we have excluded those who completed the 12 th grade that the effect becomes statistically significant, a refinement in the sample that is, to the best of our knowledge, new in the literature.

${ }^{26}$ Although many previous studies distinguish between older and younger teens to look for labor substitution effects, the results show that this approach is limited, since the substitution does not occur within teenagers but is directed towards older and more educated workers.

${ }^{27}$ These results are consistent with several other findings in the literature. For example
} 
Now we analyze these results under the light of our model. According to our model, more productive workers have higher participation and employment rates, and wages, so demographic groups could be ranked by productivity based on their observed outcomes. Figure 3 shows the participation rate, employment rate, and average wage in terms of the minimum, by age and education. Interpreting these outcomes through the model would place low-education teenagers at the bottom of the productivity distribution. This demographic also has the highest share of workers earning no more than $10 \%$ over the minimum, making it the obvious candidate to examine the effects of the policy. However, our model predicts that the policy not only affects those directly bound by it, but, through a general equilibrium effect, it also affects any other worker participating in the same labor market. The only other demographic showing statistically significant results is prime-aged workers with high school education, who according to Figure 3 and Table ??, are not only significantly more productive than teenagers, but are also mostly out of the reach of a $10 \%$ increase in the minimum.

The implication, according to our model, is that both demographics participate in the same labor market, which tightens with increments in the minimum as teenage participation drops. ${ }^{28}$ This tightening of the market increases the participation and employment of the low-education prime-aged. The model also helps to understand why it is only the most and least productive of the low-education demographics that display elasticities statistically different from zero. $^{29}$ The productivity ranking implied by Figure 3 refers to the average worker, and large productivity heterogeneity could exist within each of the two-way demographics. Within each of these groups, a rise in the minimum could price out some workers while benefiting others, rendering an average change difficult to identify in our regressions. If statistically significant results are found only for what could be considered the least and most productive of the low-education groups, it must be because the rise in the minimum has a mostly homogeneous effect within these groups, while in the rest of the low-education demographics, being of "middle" low-productivity, there is no

Neumark and Wascher (2007) also report insignificant employment effects for workers under 25 with HS education.

${ }^{28}$ According to the BLS, $26 \%$ of total jobs in 2012 had no educational requirements. In the same year, only $8 \%$ of the labor force had less than high school educational attainment. This suggests that there is a significant size of workers with at least high school education that complete in the labor market with those less educated, reinforcing the idea that workers with low education participate in the same labor market.

${ }^{29}$ In some market outcomes elderly workers outperform prime-age workers; however the labor market conditions of elderly workers are understandably determined by conditions other than productivity, making it difficult to fully be consistent with the model. 
homogeneous way in which workers are affected by the policy; hence the absence of statistical significance.
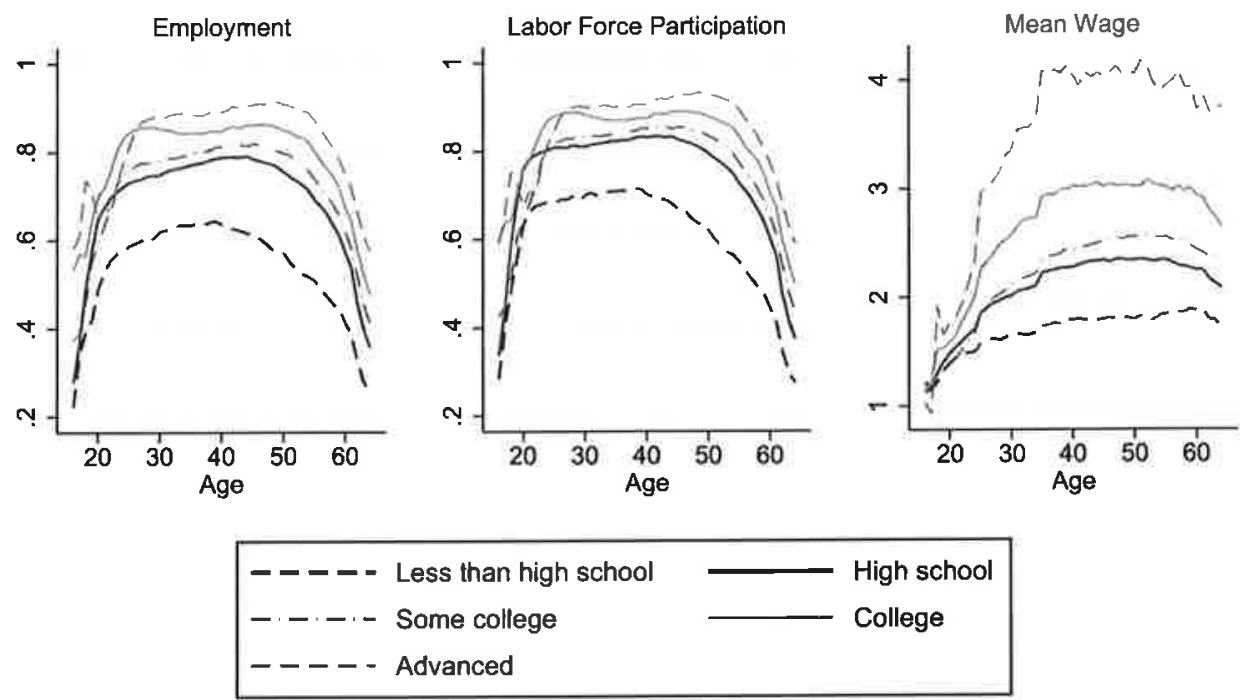

Figure 3: Market Outcomes by Education and Age

Figure 3 suggests that, on average, workers with higher education (some college, college, and advanced) are more productive than low-education workers. The absence of propagation of any effect to these groups suggests that they do not participate in the same labor market as low-education workers, and therefore do not benefit from the tighter market that the trimming of teenagers produces.

It must be pointed out that accompanying the positive employment and participation effects, the model predicts wage increments. In theory, a tighter market increases workers' unemployment value and higher wages are demanded to compensate for this. However, wage elasticities of prime-age workers with high school education are statistically indistinguisable from zero; the more advantageous bargaining position of a tighter market is not sufficiently strong to be captured by our regressions. This might be due to the fact that short-term wage rigidities prevent the immediate adjustment that the model predicts. In reality, the wage gains of this demographic might materialize only gradually. Also, the improvement in effective bargaining strength might materialize as other job benefits, such as flexible hours or bonuses, that are missed by our measure of wages. ${ }^{30}$ Our regressions show evidence of a wage rise only for

\footnotetext{
${ }^{30}$ Our results might be linked to the broader recent phenomenon of wages not responding
} 
teenagers. This is not at odds with the model, considering that the wages observed after an increase in the minimum are those from teenagers escaping the cut; the most productive ones. So the statistically significant effect on wages is reflecting both the increased representation of teenagers with the highest wage and the direct wage increment of a binding minimum.

The loss of employment and labor force participation of teenagers and the parallel gains for low-education prime-aged workers, makes the impact on aggregate low-education worker welfare unclear. We investigate this issue in the next section through simulations of increments in the minimum wage using a calibrated version of our model.

\section{Quantitative Exercises}

To calibrate the model, functional forms of the matching function and the cost of search are necessary. For the matching function, the Cobb-Douglas $h\left(\sum p_{i} s_{i} u_{i}, v\right)=\tau\left(\sum p_{i} s_{i} u_{i}\right)^{\eta} v^{1-\eta}$ is assumed, where $\tau>0$ is the efficiency of matching parameter, and $\eta$ is elasticity with respect to the measure of searching workers. Following Christensen et al. (2005), the search-cost function is defined as

$$
c(s)=c_{0} \frac{s^{1+1 / \alpha}}{1+1 / \alpha}
$$

with $c_{0}>0$ and $\alpha>0$. These assumptions leave us with nine parameter values and a worker productivity distribution to determine. We take values for $r, \eta$, and $b$ from the literature, and set the values of $\gamma, \delta, \tau, \alpha$, and $c_{o}$ to match key statistics of the U.S low-education labor market under different values of the worker's bargaining weight, $\beta$, for comparison. ${ }^{31}$ Simultaneously, we use these values to infer worker productivities from the observed wage distribution.

Periods are set to quarters, so the discount rate is $r=0.012$, which corresponds to an annual discount factor of 0.953. According to Petrongolo and

to a tightening market. See Leduc et al. (2017) and Byrne et al. (2018). The linkage of market tightness and wages is certainly a topic for future exploration.

${ }^{31}$ The standard efficiency Hosios (1990) condition would require $\beta=\eta=0.6$. As Flinn (2006) remarks, there is no special reason to believe that, even in the representative worker case, efficiency is achieved. He estimates this bargaining parameter, and his results suggest that value of this parameter is above levels where further increments would generate welfare gains. Moreover, as discussed in Section 3, in the presence of productivity heterogeneity this condition does not guarantee efficiency. 
Pissarides (2001), the range of estimated values of $\eta$ across the literature is $[0.5,0.7]$, so we set it to $\eta=0.6$. Since one of the insights of the model is that the nonmarket value of unemployment has important welfare implications, we consider two values for this parameter. Hall and Milgrom (2008) report that empirical studies measuring unemployment insurance place it between $12 \%$ and $36 \%$ of the employee's former wage, so we first set $b=0.25$, which corresponds to an income replacement ratio of $25 \%$ of the mean of our normalized wage distribution. This value also implies an income replacement ratio for the least productive worker of $40 \%$, which corresponds to Shimer (2005) calibration. The second value considered is $b=0.6$. This is equivalent to having an income replacement ratio for the least productive worker of $95.5 \%$, following Hagedorn and Manovskii (2008).

Using CPS observations of 16-64 year-olds with high school or less education, we compute our calibration targets. The aggregate employment rate is $62 \%$, and the labor force participation rate is $68 \%$. Average unemployment duration is 1.58 quarters. ${ }^{32}$ With the theoretical expressions for each of these statistics, we form the system of equations:

$$
\begin{gathered}
\text { Aggregate Employment }=\sum_{i} p_{i}\left(1-u_{i}\right)=0.62 \\
\text { Labor Force Participation }=\sum_{i} p_{i}\left(1-u_{i}\right)+\sum_{i} p_{i} s_{i} u_{i}=0.68 \\
\text { Average Unemployment Duration }=1 /\left(\tau \theta^{1-\eta}\right)=1.58
\end{gathered}
$$

Although $\theta$ is an endogenous variable, the calibration requires a baseline steady-state value. Hagedorn et al. (2016) estimate the market tightness for the low-education labor market to be $\theta^{\text {LowEd }}=0.5858$. With this value, we use the VSC (12) as the fourth equation in our system to guarantee that the calibration parameters are consistent with a steady state. The VSC requires productivity values $\left\{y_{i}\right\}_{i=1}^{n}$, which can be recovered from observed wages using the steady-state Nash-bargaining wage solution

$$
y_{i}=w_{i}^{o b s}\left[\frac{r+\delta+\beta s_{i} \tau \theta^{1-\eta}}{\beta\left(r+\delta+s_{i} \tau \theta^{1-\eta}\right)}\right]-\left[\frac{(r+\delta)((1-\beta)}{\beta\left(r+\delta+s_{i} \tau \theta^{1-\eta}\right)}\right]\left[b-c_{0} \frac{s_{i}^{1+1 / \alpha}}{1+1 / \alpha}\right] .
$$

\footnotetext{
${ }^{32}$ These targets are computed as the average of the weighted monthly observations from 1997 to 2013.
} 
The unconstrained solution prescribes a one-to-one mapping from productivity to wages. However, given the censorship of a binding minimum, additional assumptions are required to recover the productivity distribution. We assume that the productivity of those workers earning the minimum wage is uniformly distributed between $m$ and $\bar{y}(14)$, the productivity level such that the Nashbargaining wage is equal to the minimum. The optimal $s_{i}$ is obtained using equation (4) expressed in terms of the observed wage.

Finally, we set the parameter of the elasticity of the cost function, $\alpha$, to match the minimum wage elasticity of employment of prime age workers with high school attainment. The results in Section 4 place the point elasticity around 0.05 . Considering that the average increase of the minimum wage in our sample is $8.9 \%$, we set $\alpha$ such that a $9 \%$ increase in the minimum generates an increase of $0.45 \%$ in the employment of the top quintile of the productivity distribution. This way, for a given value of $\beta$ and an empirical wage distribution $\left\{w_{i}^{o b s}, p_{i}^{o b s}\right\}_{i=1}^{k}$, the system of equations is solved using a value of $\alpha$ that gives sensible values of the elasticities in the simulations. See Appendix B for more details on the calibration. Table 2 presents combinations of $\beta$ and our two considered values for $b$ that meet all of our calibration targets. Figure 6 shows the calibrated wage-productivity mapping, and Figure ?? the calibrated productivity distributions.

The fact that our calibrated values for $\tau$ and $\delta$ do not depend on the choice of $\beta$ reflects the recursive nature of our system of equations. As shown in Appendix B, $\beta$ enters the system only through the firm's expected profits in equation (12), which is used to pin down the value of $\gamma$. This way, for a fixed equilibrium market tightness, a higher bargaining weight implies lower vacancy costs. Our value for the separation rate of 0.061 is considerably lower than the separation rate for low-skilled workers computed by Hagedorn et al. (2016) of 0.11 , or the total non-farm separation rate of 0.1 reported by the BLS. However, our calibration requires this specific value for the separation rate to guarantee the aggregate unemployment rate is equal to the one implied by our targets for aggregate employment and participation rates.

The asymmetries in outcomes reported in Section 4 suggests the presence of small firm surpluses, since for a rise in the minimum to tighten the market, the wedge between unconstrained Nash wages and productivity must be small. Our calibration results confirm this. With the standard values of $b=0.25$, and $\beta$ set to satisfy the Hosios (1990) condition, $\beta=0.6$, the model cannot meet the elasticity of employment target. Given a collection of observed wages, the standard calibration implies large worker productivities. Therefore, an increase of $9 \%$ of $m$ does not price out enough workers for the market to tighten 
Table 2: Calibration Results

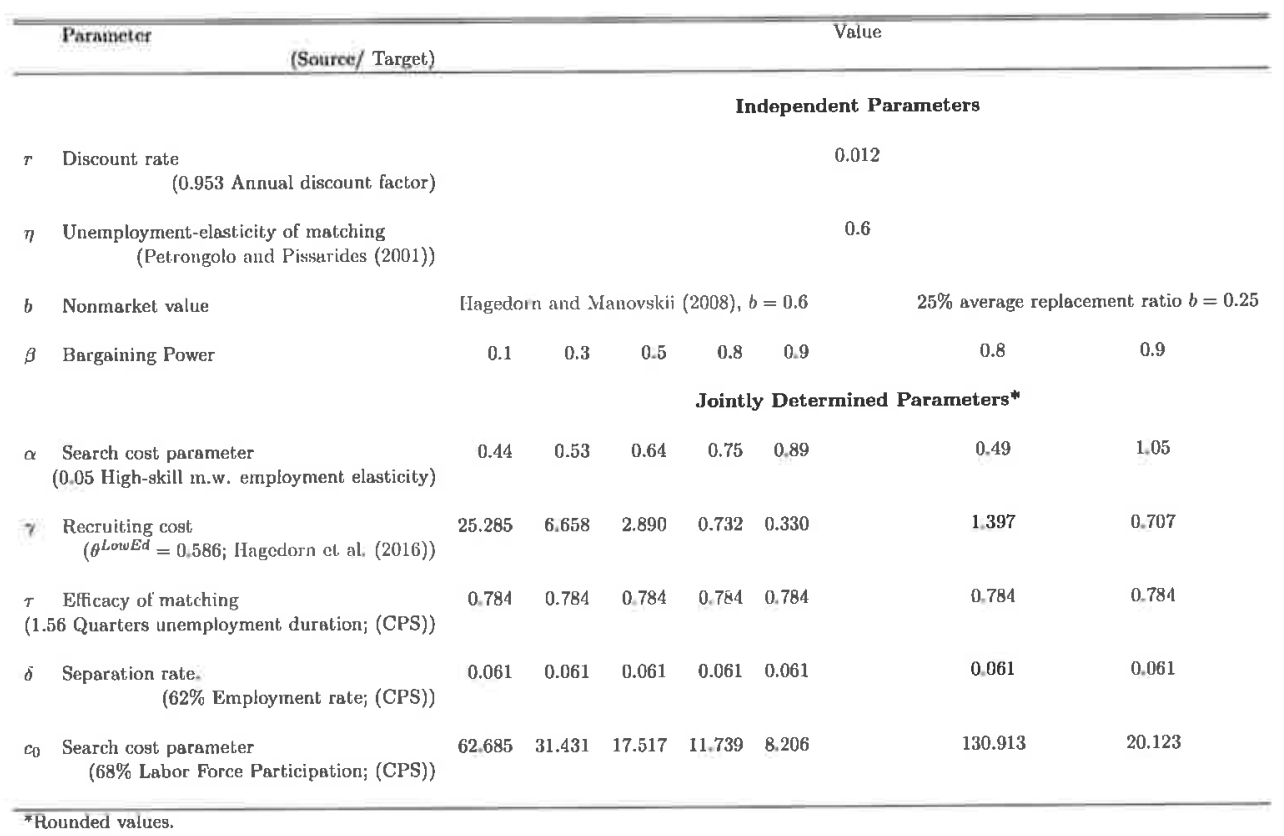

and generate the desired asymmetries. If $b=0.25$, then $\beta$ must be roughly above 0.78 to match the employment response of prime-age low education workers. In other words, if $b=0.25$ and $\beta<0.78$, there are no values of $\alpha$ under which the model meets all of our targets. We report the results of the calibration with $b=0.25$ for values $\beta=0.8$ and $\beta=0.9$, for which there is a value of $\alpha$ that meets the elasticity of employment target.

When $b=0.6$, the model can match the estimated employment elasticity for several values of $\beta$. As mentioned earlier, this value of the nonmarket activity implies a Hagedorn and Manovskii (2008) type of workers at the low end of the productivity distribution, in the sense that their associated fundamental surplus is close to zero. So, even for low values of the worker's bargaining weight, firm surplus is limited. ${ }^{33}$ A high value of nonmarket activity implies

33 There is an interesting connection between our paper and the unemployment volatility puzzle. Although there are no business cycle productivity shocks in our model, a rise in the minimum does generate a change in the expected output of the match from the firm's perspective. Under a standard calibration, our model also struggles to generate responses in vacancy creation strong enough to match our estimated minimum wage employment elasticities. Hagedorn and Manovskii (2008) note that for the Montensen Pissarides model to generate plausible responses of employment from aggregate productivity shocks, the ac- 
productivities close to the observed wages at the low end of the distribution, so an increase in the minimum does price out enough workers to tighten the market and meet our employment target. Next, we perform some numerical exercises under some of our calibrations that meet all of our targets.

\subsection{Minimum Wage Simulations}

We use the calibrated model to investigate the effects of increments in the minimum wage on the steady-state values of employment, labor force participation, and payroll. We report worker welfare, defined as $\sum p_{i} u_{i}\left[b-c\left(s_{i}\right)\right]+$ $\sum p_{i}\left(1-u_{i}\right) w_{i}$, to weigh the impact on employment and participation against the impact on wages. We also report total welfare, (15), to take into account the impact on firm welfare.

We report the aggregates of the outcomes and the results for the lowest and highest quintiles of the productivity distribution. Figure 4 shows the elasticities of the several outcomes with respect to the minimum wage, and Table 3 reports results for our benchmark $9 \%$ increase in $m$, a $50 \%$ increase in $m$, and the optimal increase in $m$ associated with each calibration.

For relatively small increments of $m$ the model performs similarly in terms of employment, labor force participation, and wages across the different calibrations. In general, the outcomes show moderate improvements for the top quintile of the distribution that contrast with stronger negative impacts on the least productive. For example, a $9 \%$ increase in the minimum generates employment losses for the bottom quintile that range from $17 \%$ to $52 \%$ depending on the calibration, and implies gains in the employment of the most productive of $0.45 \%$ by construction. All of the different calibrations show that

counting profits of the firm must be sinall. This is the case in our model too, although the mechanism is different. In our model, small accounting profits imply relatively high wages, which guarantees that the direct wage "bump" of the policy is small, and therefore the market tightens. The market must also tighten enough. The increase in the firm's expected match output that a rise in the minimum generates must be large relative to the firm's accounting profit, just like in the unemployment volatility puzzle. One key difference of our model is that we are not concerned with the elasticity of wages, since the increase in the firm's expected match output does not increase the productivity of a particular worker; workers do not benefit directly from the "productivity shock" of a rise in the minimum. This is why our desired response can be achieved even for high values of the Bargaining parameter; the incentive for vacancy creation is not absorbed by wages as it would be in the case of an increase in aggregate labor productivity. Although, as Ljungqvist and Sargent (2017) remark, it is small fundamental surpluses that are crucial for vacancy creation to be responsive enough. 
indeed, the asymmetries in outcomes imply a widening of the welfare between the most and least productive workers; a higher minimum slightly increases the welfare of the most productive workers, while it has the opposite effect on the least productive. However, in terms of aggregate welfare, the calibrations display important differences depending on the nonmarket activity value $b$. For a standard calibration that interprets $b$ as an average income replacement ratio, $b=0.25$, small increments in $m$ generate a reduction in aggregate welfare. However, in the calibrations with $b=0.6$ a rise in the minimum has a positive impact on aggregate welfare even for high values of worker bargaining power. In our benchmark $9 \%$ increase of $m$, when $\beta=0.9$, if $b=0.25$, aggregate welfare drops $1.33 \%$, while if $b=0.6$, aggregate welfare increases $0.2 \%$.

This result clearly shows that in the presence of heterogeneity the Hosios (1990) efficiency condition does not hold; even when $\beta$ is higher than the matching elasticity parameter $\eta$, a rise in the minimum can improve aggregate welfare if the nonmarket activity of workers is high. This is due to the fact that heterogeneity in productivity creates a distribution of match surpluses. ${ }^{34}$ A higher minimum wage impacts welfare negatively through the destruction of the fundamental surplus of the least productive matches. A Hagedorn and Manovskii (2008)-type calibration for the nonmarket value implies near zero match surpluses at the low end of the distribution, so the surplus loss from a rise in the minimum is negligible. This contrasts with the situation when $b$ is low. Low values of $b$ imply significant fundamental surpluses even for the least productive workers. When the minimum rises, the loss of match surplus is too strong to be counteracted by the creation of matches with higher surplus that the asymmetric effects of the minimum generates.

With an increase of $50 \%$, stark differences in outcomes across calibrations appear. For an increase in the minimum this high, not only $b$, but also $\beta$ largely determine the impact on welfare. While the most productive workers still benefit at the expense of the least productive, the cost in welfare for the latter group could be as high as $42 \%$ depending on the value of $\beta$. Also, a 50 $\%$ increment would price out entirely the lowest quintile of workers under most of our calibrations, while having only a moderate impact on the employment, $3 \%$, labor force participation, $1.5 \%$, and payroll, $3 \%$, of the most productive workers. Again, when $b=0.6$, an increase of $50 \%$ can generate aggregate welfare improvements, of up to $2.65 \%$, but this time only for values of the bargaining weight that are not too high. Our calibrations with $b=0.25$

\footnotetext{
${ }^{34}$ See Ortcgo-Marti (2017), and Lalé (2018) for examples of endogenous match surplus distributions through human capital acquisition and depreciation.
} 
predict a significant loss in aggregate welfare of around $11.5 \%$.

The impact of a minimum on aggregate welfare, as defined by (15), is not monotonic, so it is possible to numerically find the aggregate welfare maximizing increase of $m$. Table 3 shows the optimal increase of $m$ for each of our calibrations, and its effect on outcomes. When $b=0.25$, any increment in $m$ can only reduce aggregate welfare. The optimal increase in $m$ is zero. For $b=0.6$, increments in $m$ do have a monotonic impact. The implied optimal increase is larger for smaller values of the bargaining weight $\beta$. For our largest considered value of $\beta=0.9$, the optimal increase is $14 \%$, above the average increase of $9 \%$ in our sample. This optimal rise would increase aggregate welfare by $0.21 \%$, but would generate asymmetries that considerably harm the least skilled workers; it would reduce their employment, participation and payroll by $84 \%$, and their welfare by $25 \%$.

When $\beta=0.1$, the optimal increase in $m$ is $270 \%$. As Figure ?? shows, such a low value for $\beta$ implies large productivities, so even an increase of $270 \%$ does not completely price out the labor force; the impact on aggregate employment is $-43 \%$. Despite the large negative effect on employment and participation, there is an aggregate welfare gain of $20 \%$ associated with this increase. The impact in welfare is not symmetric. Whereas the top quintile experiences a $41 \%$ increase in their welfare, the welfare for the lowest quintile is reduced by $38 \%$. Notice that although this optimal increase would completely drive the lowest quintile of workers out of the labor force, the impact on their welfare is limited, no greater than $38 \%$ across the different calibrations. This is due to the near indifference between market and nonmarket activity that $b=0.6$ implies for the least productive workers; there is little loss of social welfare associated with the destruction of these matches.

To summarize, this exercise has shown that a standard calibration of the model cannot generate the asymmetries in outcomes observed in the data since it implies too large firm surpluses. For the calibration to match the positive employment response of the most productive workers, small firm surpluses are needed, so moderate increments in the minimum prices out enough workers without endogenously increasing the wages of those workers that remain. Small firm surpluses can be generated by either a high nonmarket activity value, and/or a high worker bargaining weight. However, whether it is the nonmarket value or the bargaining weight that generates small firm surpluses, has important welfare implications. A high value of nonmarket activity creates near zero surplus matches at the low end of the productivity distribution. This is a dead-weight for society that affects the formation of matches with higher surpluses through search externalities. In this case, a higher minimum eliminates this dead-weight, which increases social welfare even for high values 
of worker bargaining power.

While the assumption that a representative worker has a nonmarket value as high as $95 \%$ of his market value has come under scrutiny, there are two considerations to keep in mind in the current setting. ${ }^{35}$ First, such a high nonmarket value applies only to the least skilled workers of the distribution. A value of $b=0.6$ generates a distribution of nonmarket replacement values, with $33 \%$ for the most productive worker. An additional consideration, and perhaps a more important one, is that our modeling assumptions aim to describe low-wage labor markets, and not the representative worker in the economy. Our empirical analysis describes a rough mapping from the productivity distribution into demographic groups, which allows us to better assess our assumptions regarding nonmarket activities. If the least educated teenagers are at the bottom of the productivity distribution, as the data suggests, the idea that they might be close to indifferent between market and nonmarket activity might not be far-fetched.

Pondering on the distribution of nonmarket replacement values for different low-wage demographics is fundamental for the assessment of the policy in terms of welfare. Our simulations show that if the matches destroyed by a rise in the minimum have a negligible contribution to welfare when compared to the matches that could be created due to their destruction, then the policy could bring welfare improvements even for high values of bargaining weight.

\section{Concluding Remarks}

We explored the notion that minimum wages affect low-skilled workers asymmetrically depending on their productivity. CPS data shows that a higher minimum does have an asymmetric effect on low-education workers; it increases the employment and participation of low-education prime age workers at the expense of the employment and participation of the least educated teenagers, which implies a widening of the welfare gap between these two populations. However, the overall impact on welfare depends on the value of the workers' nonmarket activity. If it is high enough to make workers priced out by the

\footnotetext{
${ }^{35}$ As Pissarides (2009) remarks, the assumption that the representative worker is almost indifferent between market and nonmarket participation seems far-fetched. Additionally, as described by Costain and Reiter (2008), such high nonmarket values imply implausibly large unemployment elasticities with respect to labor market policies such as unemployment insurance. Hall and Milgrom (2008) also note that nonmarket values this high imply unrealistically high labor supply elasticities.
} 
policy almost indifferent between employment and non-participation, a rise in the minimum increases aggregate welfare even if the worker's Nash-bargaining weight is well above the elasticity of the matching function with respect to the unemployed. The Hosios (1990) criterion for optimality does not hold in the presence of worker heterogeneity.

These results and insights have important implications for a minimum wage implementation and evaluation, and call for a series of remarks. They underscore that the assessment of the policy must go beyond its impact on employment. Our estimates, along with many others in the empirical literature, point to small employment losses. However, worker heterogeneity introduces the possibility that even if aggregate levels of employment and payroll declined, the policy could have aggregate welfare improvements. In our model, the minimum affects total welfare primarily by destroying the matches with the lowest surplus in favor of higher surplus ones. Even under our stylized assumption of nonmarket value homogeneity, a higher minimum can lead to welfare improvements if the marginal workers priced out by the policy are nearly indifferent between nonmarket and market participation. Therefore, the extent to which the minimum increases social welfare depends on the underlying nonmarket activity values of workers directly and indirectly affected by the policy. If teenagers with less than high school education are close to indifferent between work and leisure, because of the possibility of education and external financial support, but the prime-aged with high school education, far from having a positive nonmarket value, face an unemployment cost due to social stigma, human capital depreciation, and financial obligations, then a rise in the minimum would have significant welfare improvements. ${ }^{36}$

Our analysis also shows that an optimal implementation of the policy requires an accurate estimate of the worker's bargaining weight. However, the estimation of this parameter is not trivial and the results could vary widely, depending on the assumptions regarding the job searching process. ${ }^{37}$ Addition-

${ }^{36}$ As Hornstein et al. (2011) remark, although "psychological" strong costs of unemployment would seem plausible from the perspective of the health and social behavioral sciences, negative values of nonmarket activity would have serious implications for business cycle analysis and our understanding of the aggregate labor supply.

${ }^{37}$ The main consideration is whether OTJ search is allowed. Our model assumes that only the unemployed search for jobs, and while this assumption greatly simplifies the model, a more realistic setting would allow OTJ search. As many previous studies show, the presence of OTJ search considerably lowers the estimated values for this parameter, and it is unclear what the welfare implications of a higher minimum under these circumstances might be. For estimates allowing for OTJ search see Dey and Flinn (2005), Cahuc ct al. (2006), Flinn and Mabli (2009), Flinn and Mullins (2015), and Flinn ct al. (2017). For estimates not allowing for OTJ search see Flinn (2006). 
ally, recent works on labor market concentration suggest that the bargaining strength of workers might vary regionally, across sectors, and time. ${ }^{38}$ Considering these differences in the design of the policy is fundamental.

An additional remark concerning the evaluation of the policy must be made. We have analyzed the impact of the policy in terms of employment, labor force participation, and wages. However, if the policy's goals are poverty reduction and supporting low-income households, one must not equate the impact that the policy has on our concept of welfare with the degree to which the policy achieves these goals. Other socioeconomic considerations that escape our model are needed to make the distinction between low-skilled workers and low-income households. We must incorporate the possibility that teenagers priced out by the policy might not significantly contribute to the welfare of low-income households, while low-education prime-aged workers could. With these considerations in mind, our findings could be compatible with those of Dube (2018), who finds that higher minimum wages increase household incomes at the bottom of the income distribution, and also reduce poverty rates.

\section{References}

Acemoglu, D. (1999). Changes in unemployment and wage inequality: an alternative theory and some evidence. American Economic Review 89(5), $1259-1278$.

Ahn, T., P. Arcidiacono, and W. Wessels (2011). The distributional impacts of minimum wage increases when both labor supply and labor demand are endogenous. Journal of Business \& Economic Statistics 29(1), 12-23.

Allegretto, S., A. Dube, M. Reich, and B. Zipperer (2017). Credible research designs for minimum wage studies: A response to Neumark, Salas, and Wascher. ILR Review $70(3), 559-592$.

Allegretto, S. A., A. Dube, and M. Reich (2011). Do minimum wages really reduce teen employment? accounting for heterogeneity and selectivity in state panel data. Industrial Relations: A Journal of Economy and Society 50(2), 205-240.

Azar, J., I. Marinescu, and M. I. Steinbaum (2017). Labor market concentration.

Azar, J., I. Marinescu, M. I. Steinbaum, and B. Taska (2018). Concentration in us labor markets: Evidence from online vacancy data.

\footnotetext{
${ }^{38}$ Azar et al. (2017) and Azar et al. (2018)
} 
Belman, D. and P. J. Wolfson (2014). What does the minimum wage do? WE Upjohn Institute.

Benmelech, E., N. Bergman, and H. Kim (2018). Strong employers and weak employees: How does employer concentration affect wages? Technical report, National Bureau of Economic Research.

Bertrand, M., E. Duflo, and S. Mullainathan (2004). How much should we trust differences-in-differences estimates? The Quarterly journal of economics 119(1), 249-275.

Byrne, D., Z. Zekaite, et al. (2018). Missing wage growth in the euro area: is the wage philips curve non-linear? Technical report, Central Bank of Ireland.

Cahuc, P., F. Postel-Vinay, and J.-M. Robin (2006). Wage bargaining with on-the-job search: Theory and evidence. Econometrica 74(2), 323-364.

Cengiz, D., A. Dube, A. Lindner, B. Zipperer, et al. (2018). The effect of minimum wages on low-wage jobs: Evidence from the united states using a bunching estimator. Technical report, Centre for Economic Performance, LSE.

Chassamboulli, A. (2011). Cyclical upgrading of labor and employment differences across skill groups. The BE Journal of Macroeconomics 11(1), 1-42.

Christensen, B. J., R. Lentz, D. T. Mortensen, G. R. Neumann, and A. Werwatz (2005). On-the-job search and the wage distribution. Journal of Labor Economics 23(1), 31-58.

Costain, J. S. and M. Reiter (2008). Business cycles, unemployment insurance, and the calibration of matching models. Journal of Economic Dynamics and control 32(4), 1120-1155.

Dey, M. S. and C. J. Flinn (2005). An equilibrium model of health insurance provision and wage determination. Econometrica 73(2), 571-627.

Dickens, R. and A. Manning (2004). Spikes and spill-overs: The impact of the national minimum wage on the wage distribution in a low-wage sector. The Economic Joumal 114(494).

Dolado, J. J., M. Jansen, and J. F. Jimeno (2009). On-the-job search in a matching model with heterogeneous jobs and workers. The Economic Journal 119(534), 200-228.

Doucouliagos, H. and T. D. Stanley (2009). Publication selection bias in minimum-wage research? a meta-regression analysis. British Journal of Industrial Relations 47(2), 406-428.

Drazen, A. (1986). Optimal minimum wage legislation. The Economic Journal 96(383), 774-784.

Dube, A. (2018). Minimum wages and the distribution of family incomes.

Dube, A., L. M. Giuliano, and J. S. Leonard (2015). Fairness and frictions: 
The impact of unequal raises on quit behavior. IZA Discussion Paper No. 9149 .

Dube, A., T. W. Lester, and M. Reich (2010). Minimum wage effects across state borders: Estimates using contiguous counties. The Review of Economics and Statistics 92(4), 945-964.

Engbom, N. and C. Moser (2017). Earnings inequality and the minimum wage: Evidence from brazil.

Fairris, D. and L. F. Bujanda (2008). The dissipation of minimum wage gains for workers through labor-labor substitution: evidence from the los angeles living wage ordinance. Southern Economic Journal, 473-496.

Falk, A., E. Fehr, and C. Zehnder (2006). Fairness perceptions and reservation wages-the behavioral effects of minimum wage laws. The Quarterly Journal of Economics 121(4), 1347-1381.

Flinn, C., A. Gemici, and S. Laufer (2017). Search, matching and training. Review of Economic Dynamics 25, 260-297.

Flinn, C. and J. Mabli (2009). On-the-job search, minimum wages, and labor market outcomes in an equilibrium bargaining framework. new york university.

Flinn, C., J. Mabli, and J. Mullins (2017). Firms' choices of wage-setting protocols in the presence of minimum wages. Working Paper.

Flinn, C. and J. Mullins (2015). Labor market search and schooling investment. International Economic Review 56(2), 359-398.

Flinn, C. J. (2006). Minimum wage effects on labor market outcomes under search, matching, and endogenous contact rates. Econometrica 74(4), 10131062.

Freeman, R. B., W. B. Gray, and C. Ichniowski (1981). Low-cost student labor: The use and effects of the subminimum wage provisions for full-time students.

Giuliano, L. (2013). Minimum wage effects on employment, substitution, and the teenage labor supply: Evidence from personnel data. Journal of Labor Economics 31(1), 155-194.

Gorry, A. (2013). Minimum wages and youth unemployment. European Economic Review 64, 57-75.

Hagedorn, M. and I. Manovskii (2008). The cyclical behavior of equilibrium unemployment and vacancies revisited. American Economic Review 98(4), 1692-1706.

Hagedorn, M., I. Manovskii, and S. Stetsenko (2016). Taxation and unemployment in models with heterogeneous workers. Review of Economic Dynamics 19, 161-189.

Hall, R. E. and P. R. Milgrom (2008). The limited influence of unemployment 
on the wage bargain. The American Economic Review 98(4), 1653-1674.

Hornstein, A., P. Krusell, and G. L. Violante (2011). Frictional wage dispersion in search models: A quantitative assessment. American Economic Review 101(7), 2873-98.

Hosios, A. J. (1990). On the efficiency of matching and related models of search and unemployment. The Review of Economic Studies 57(2), 279-298.

Jaeger, D. A. (1997). Reconciling the old and new census bureau education questions: Recommendations for researchers. Journal of Business \& Economic Statistics 15(3), 300-309.

Jardim, E., M. C. Long, R. Plotnick, E. Van Inwegen, J. Vigdor, and H. Wething (2017). Minimum wage increases, wages, and low-wage employment: Evidence from seattle.

Kaitz, H. B. (1970). Analyzing the length of spells of unemployment. Monthly Lab. Rev. 93, 11-20.

Katz, L. F. and A. B. Krueger (1992). The effect of the minimum wage on the fast-food industry. ILR Review 46(1), 6-21.

Krueger, A. and E. Posner (2018). A proposal for protecting low-income workers from monopsony and collusion. Policy Proposal 1.

Krueger, A. B. (2018). Reflections on dwindling worker bargaining power and monetary policy. In Luncheon Address at the Jackson Hole Economic Symposium.

Lalé, E. (2018). Loss of skill and labor market fluctuations. Labour Economics $50,20-31$.

Leduc, S., D. J. Wilson, et al. (2017). Has the wage phillips curve gone dormant? FRBSF Economic Letter 2017, 30.

Lee, D. and E. Saez (2012). Optimal minimum wage policy in competitive labor markets. Journal of Public Economics 96(9-10), 739-749.

Ljungqvist, L. and T. J. Sargent (2017). The fundamental surplus. American Economic Review 107(9), 2630-65.

Luttmer, E. F. (2007). Does the minimum wage cause inefficient rationing? The BE Journal of Economic Analysis \& Policy 7(1).

Meer, J. and J. West (2015). Effects of the minimum wage on employment dynamics. Journal of Human Resources.

Mincer, J. (1976). Unemployment effects of minimum wages. Journal of Political Economy 84(4, Part 2), S87-S104.

Neumark, D. and O. Nizalova (2007). Minimum wage effects in the longer run. Journal of Human resources 42(2), 435-452.

Neumark, D., J. I. Salas, and W. Wascher (2014). Revisiting the minimum wageemployment debate: Throwing out the baby with the bathwater? ILR Review 67(3_suppl), 608-648. 
Neumark, D. and W. Wascher (1995). Minimum wage effects on employment and school enrollment. Journal of Business \& Economic Statistics 13(2), 199-206.

Neumark, D. and W. Wascher (2007). Minimum wages and employment. Foundations and Trends( $\mathrm{B}$ in Microeconomics 3(1-2), 1-182.

Neumark, D. and W. Wascher (2017). Reply to "Credible Research Designs for Minimum Wage Studies". ILR Review 70(3), 593-609.

Neumark, D. and W. L. Wascher (2008). Minimum wages. MA: MIT Press, Cambridge.

Obenauer, M. L. and B. M. von der Nienburg (1915). Effect of Minimum-wage Determinations in Oregon: July, 1915. Number 6. US Government Printing Office.

Ortego-Marti, V. (2017). The cyclical behavior of unemployment and vacancies with loss of skills during unemployment. Macroeconomic Dynamics 21(6), 1277-1304.

Petrongolo, B. and C. A. Pissarides (2001). Looking into the black box: A survey of the matching function. Journal of Economic literature 39(2), 390-431.

Phelan, B. (2014). Labor supply substitution and the ripple effect of minimum wages. DePaul University (manuscript).

Pissarides, C. A. (2000). Equilibrium unemployment theory. MIT press.

Pissarides, C. A. (2009). The unemployment volatility puzzle: Is wage stickiness the answer? Econometrica 77(5), 1339-1369.

Pries, M. J. (2008). Worker heterogeneity and labor market volatility in matching models. Review of Economic Dynamics 11(3), 664-678.

Ragan, J. F. (1977). Minimum wages and the youth labor market. The Review of Economics and Statistics, 129-136.

Rocheteau, G. and M. Tasci (2008). Positive and normative effects of a minimum wage. Federal Reseve Bank of Cleveland Working Paper Series.

Shimer, R. (2005). The cyclical behavior of equilibrium unemployment and vacancies. American Economic Review 95(1), 25-49.

Shimer, R. and L. Smith (2001). Matching, search, and heterogeneity. Advances in Macroeconomics 1 (1).

Teulings, C. N. (2000). Aggregation bias in elasticities of substitution and the minimum wage paradox. International Economic Review 41(2), 359-398.

Tukey, J. W. (1977). Exploratory data analysis.

Wessels, W. J. (1980). The effect of minimum wages in the presence of fringe benefits: An expanded model. Economic Inquiry 18(2), 293-313.

Wessels, W. J. (2005). Does the minimum wage drive teenagers out of the labor force? Journal of Labor Research 26(1), 169-176. 

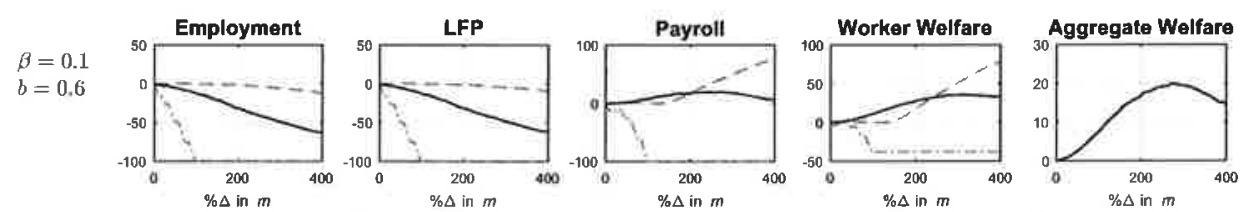

$\beta=0.3$
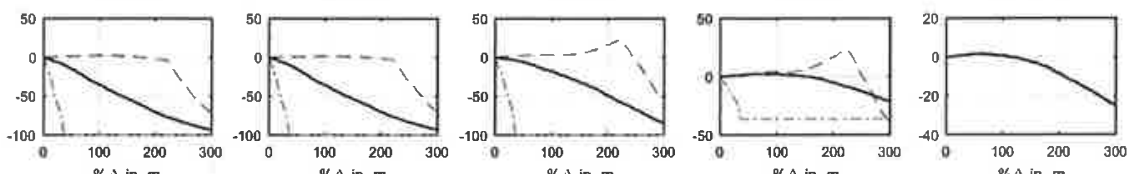

$\beta=0.5$
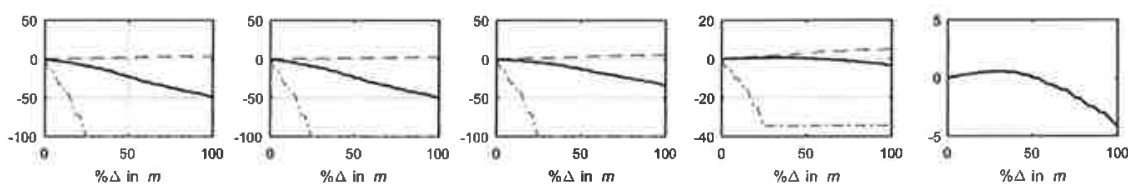

$\beta=0.8$
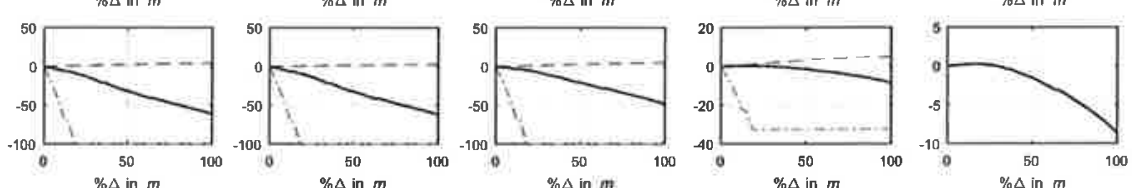

$\beta=0.9$
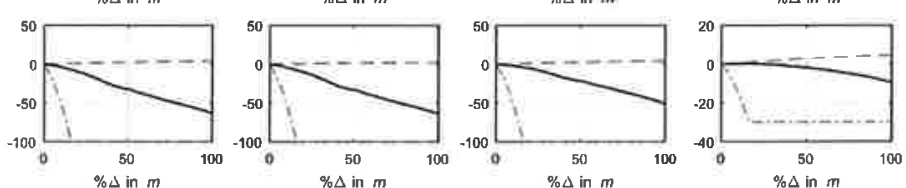

$\% \Delta$ in

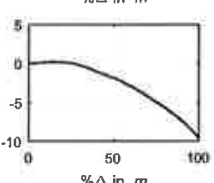

$\beta=0.8$
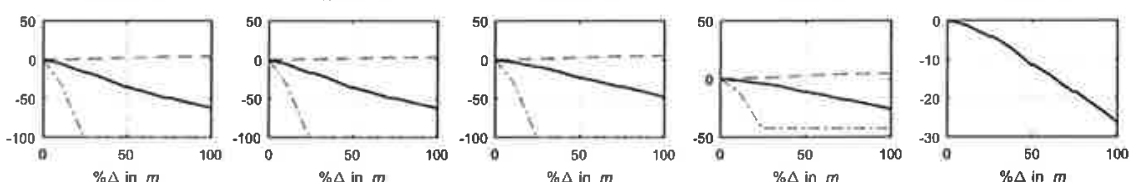

$\beta=0.9$
$b=0.25$
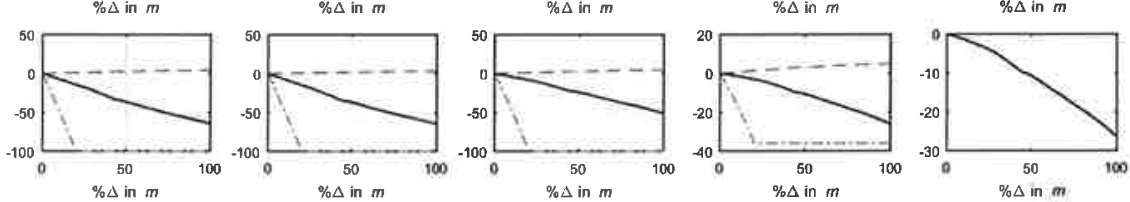

\section{- Aggregate ---Highest skilled -..--Lowest skilled}

Figure 4: Impact of a Higher Minimum Wage on Labor Market Outcomes Notes: This figure shows the elasticities of our different market outcomes with respect to a change in the minimum wage for different values of the wage bargaining weight. Lowest skilled workers include all the workers in the lowest quantile of the productivity distribution and the highest skilled workers are the workers in the upper quantile. 
Table 3: Numerical Results

\begin{tabular}{|c|c|c|c|c|c|c|c|c|}
\hline \multirow{2}{*}{$\begin{array}{l}\text { Nonmarket value } \\
\text { Bargaining Power }\end{array}$} & & \multicolumn{5}{|c|}{ Hagedorn and Yanovskii (2008) $b=0.6$} & \multicolumn{2}{|c|}{$25 \%$ Average replacement ratio $b=0.25$} \\
\hline & & 0.1 & 0.3 & 0.5 & 0.8 & 0.9 & 0.8 & 0.9 \\
\hline & & \multicolumn{7}{|c|}{ Results } \\
\hline \multicolumn{2}{|l|}{$9 \% m$ increase } & & & & & & & \\
\hline \multicolumn{2}{|l|}{$\% \Delta$ Aggregate welfare } & 0.44 & 0.36 & 0.27 & 0.20 & 0.20 & -1.17 & -1.33 \\
\hline \multirow[t]{3}{*}{$\% \Delta$ Worker welfare } & Aggregate & 0.48 & 0.39 & 0.29 & 0.21 & 0.20 & -1.13 & -1.31 \\
\hline & 5th quintile & 0.86 & 0.71 & 0.62 & 0.52 & 0.51 & 0.48 & 0.85 \\
\hline & 1st quintile & -5.07 & -7.23 & -9.94 & $-12,60$ & -14.67 & $-11,89$ & -16.71 \\
\hline \multirow[t]{3}{*}{$\% \Delta$ Employrnent } & Aggregate & -1.64 & -1.53 & -3.19 & $-3.9 \mathrm{I}$ & $-3,21$ & -4.46 & -7.71 \\
\hline & 5th quintile & 0.45 & 0.45 & 0.45 & 0.45 & 0.45 & 0.45 & 0.45 \\
\hline & 1st quintile & -17.24 & -23.57 & -31.49 & -41.07 & -51.82 & -35.53 & -52.79 \\
\hline \multirow[t]{3}{*}{$\% \Delta \mathrm{LFP}$} & Aggregate & -1.75 & -2.33 & -2.91 & -3.55 & -4.00 & -5.95 & -7.87 \\
\hline & 5th quintile & 0.34 & 0.33 & 0.32 & 0.30 & 0.29 & 0.35 & 0.56 \\
\hline & 1st quintile & -17.34 & -23.67 & -31.58 & -41.16 & -51.92 & -35.61 & -52.89 \\
\hline \multirow[t]{3}{*}{$\% \Delta$ Payroll } & Aggregate & -0.29 & $-0,75$ & -1.22 & -1.70 & -1.96 & -2.96 & -4.04 \\
\hline & 5th quintile & 0.95 & 0.76 & 0.65 & 0.51 & 0.48 & 0.51 & 0.78 \\
\hline & 1st quintile & -14.72 & -21.04 & -19.44 & -27.56 & -33.22 & -23.20 & -36.79 \\
\hline \multicolumn{9}{|l|}{$50 \% m$ increase } \\
\hline \multicolumn{2}{|l|}{$\% \Delta$ Aggregate welfare } & 2.65 & 1.52 & 0.15 & -1.41 & $-1,81$ & $-11,28$ & -11.59 \\
\hline \multirow{3}{*}{$\% \Delta$ Worker welfare } & Aggregate & 3.71 & 2.04 & 0.46 & $-1,30$ & -1.76 & -11.05 & $-11,43$ \\
\hline & 5th quintile & 2.65 & 1.52 & 2.90 & 3.19 & 3.22 & 3.18 & 3.09 \\
\hline & 1st quintile & -6.37 & -36.39 & -34.40 & -32.49 & -29.95 & -42.50 & -39.66 \\
\hline \multirow[t]{3}{*}{$\% \Delta$ Enployment } & Aggregate & -5.33 & -14.33 & -22.13 & -30.94 & $-32,51$ & -35.25 & -39.51 \\
\hline & 5 th quintile & 0.71 & 2.73 & 2.07 & 2.74 & 2.86 & 2.97 & 2.88 \\
\hline & 1st quintile & -49.29 & -100.00 & $-100,00$ & -100.00 & -100.00 & -100.00 & -100.00 \\
\hline \multirow{3}{*}{$\% \triangle L F P$} & Aggregate & -5.50 & $-14,68$ & -22.60 & $-31,56$ & -33.13 & $-35,68$ & -39.94 \\
\hline & 5th quintile & 0.54 & 1.11 & 1.45 & 1,81 & 1.92 & 2.29 & 2.21 \\
\hline & 1st quintile & -49.38 & -100.00 & -100.00 & -100.00 & -100.00 & -100.00 & -100.00 \\
\hline \multirow[t]{3}{*}{$\% \Delta$ Payroll } & Aggregate & 1.82 & -5.66 & $-12,41$ & -20.15 & -21.78 & -22.84 & -26.10 \\
\hline & 5th quintile & 1.49 & 2.62 & 3,02 & 3,14 & 2.73 & 3.40 & 3.10 \\
\hline & 1st quintile & -29.44 & $-100,00$ & $-100,00$ & -100.00 & -100.00 & -100.00 & -100.00 \\
\hline \multicolumn{2}{|l|}{ Optimal $m$ increase } & $270 \%$ & $68 \%$ & $33 \%$ & $16 \%$ & $14 \%$. & $\mathbf{0} \%$ & $0 \%$ \\
\hline \multicolumn{2}{|l|}{$\% \Delta$ Aggregate welfare } & 20.03 & 1.66 & 0.58 & 0.35 & 0.21 & 0.00 & 0.00 \\
\hline \multirow[t]{3}{*}{$\% \Delta$ Worker welfare } & Aggregate & 34.95 & 2.53 & 0.73 & 0.37 & 0.21 & 0.00 & 0.00 \\
\hline & 5th quintile & 41.46 & 3.01 & 1.76 & 1.11 & 0.76 & 0.00 & 0.00 \\
\hline & 1st quintile & -37.95 & -36.39 & $-34,40$ & -29.14 & -24.95 & 0.00 & 0.00 \\
\hline \multirow[t]{3}{*}{$\% \Delta$ Employment } & Aggregate & -43.37 & -21.61 & -11.88 & -7.70 & -6.34 & 0.00 & 0.00 \\
\hline & 5th quintile & -4.54 & 1.87 & 1.27 & 0.96 & 0.68 & 0.00 & 0.00 \\
\hline & 1st quintile & -100.00 & -100.00 & -100.00 & -92.22 & -84.44 & 0.00 & 0.00 \\
\hline \multirow[t]{3}{*}{$\% \triangle \mathrm{LFP}$} & Aggregate & -42.74 & -22.00 & -13.64 & -8.00 & -6.57 & 0.00 & 0.00 \\
\hline & 5th quintile & -3.47 & 1.37 & 0.89 & 0.64 & 0.43 & 0.00 & 0.00 \\
\hline & 1st quintile & -100.00 & -100.00 & -100.00 & -92.31 & -84.48 & 0.00 & 0,00 \\
\hline$\% \Delta$ Payroll & Aggregate & 20.14 & $-9,32$ & -5.96 & -4.00 & -3.42 & 0.00 & 0.00 \\
\hline & 5 th quintile & 10.60 & 3.24 & 183 & 1.10 & 0.72 & 0.00 & 0.00 \\
\hline & 1st quintile & -100.00 & -100.00 & -100.00 & -9031 & -83.56 & 0.00 & 0.00 \\
\hline
\end{tabular}




\section{Appendix A: Derivations and Proofs}

Lemma 1. Optimal worker participation/search intensity increases as the market tightens.

Proof. Substituting (2) and (3) into (4), differentiating the expression, and after some algebraic manipulation, it can be checked that

$c^{\prime \prime} \frac{d s}{d \theta}-\Pi f^{\prime}\left[\frac{(w-b+c(s))(r+\delta)}{(r+\delta+s \Pi f(\theta))^{2}}\right]=\frac{d s}{d \theta} \Pi f(\theta)\left[\frac{c^{\prime}(r+\delta+s \Pi f)-\Pi f(w-b+c(s))}{(r+\delta+s \Pi f(\theta))^{2}}\right]$

Since any optimal $s$ must satisfy (4), at an equilibrium, the RHS of this last expression is equal to zero. The resulting expression for $d s / d \theta$ is, by the restrictions on the parameters, positive:

$$
\frac{d s}{d \theta}=\frac{\Pi f^{\prime}}{c^{\prime \prime}}\left[\frac{(w-b+c(s))(r+\delta)}{(r+\delta+s \Pi f(\theta))^{2}}\right]>0
$$

Lemma 2. The unconstrained equilibrium Nash-bargaining wage is increasing in market tightness.

Proof. The unconstrained Nash-bargaining wage solves $\beta(J-V)=(1-\beta)(E-$

$U)$. Applying the free entry condition, $V=0$, and substituting (2), (3), and (6), one can solve for the wage expression:

$$
w^{N}=y\left[\frac{\beta(r+\delta+s \Pi f(\theta))}{r+\delta+\beta s \Pi f(\theta)}\right]+[b-c(s)]\left[\frac{(r+\delta)((1-\beta)}{r+\delta+\beta s \Pi f(\theta)}\right] .
$$

Taking the derivative w.r.t. $\theta$, and using the equilibrium condition (4) :

$$
\frac{d w^{N}}{d \theta}=\frac{(r+\delta)((1-\beta)}{r+\delta+\beta s \Pi f(\theta)}\left[\frac{\beta(y-b+c(s))}{r+\delta+\beta s \Pi f(\theta)}\right] s \Pi f^{\prime}>0 .
$$

It is straightforward to show that $\lim _{\theta \rightarrow \infty} w^{N}=y$. 
Proof of Proposition 1 : Let $u_{i}, \Pi_{i}, s_{i}$, and $w_{i}$ denote the equilibrium values under $m$, and $u_{i}^{\prime}, \Pi_{i}^{\prime}, s_{i}^{\prime}$, and $w_{i}^{\prime}$ denote the equilibrium values under $m^{\prime}$.

1. Notice that $y_{j}<m^{\prime}$ implies that $J_{j}-V<0$, so according to (8), $\Pi_{j}^{\prime}=0$. Given that the worker is never hired, the solution to (4) is $s_{j}^{\prime}=0$.

$2 \& 3$. According to (8), any worker $y_{i} \geq m^{\prime}$, is always hired. When $\theta<\theta^{\prime}$, according to Lemma 2 , we have $\max \left\{m, w_{i}^{N}(\theta)\right\} \leq \max \left\{m^{\prime}, w_{i}^{N}\left(\theta^{\prime}\right)\right\}$. Therefore when the market tightens, all hirable workers receive higher wages. From (4), it is easy to show that optimal search is strictly increasing in wages, and Lemma 1 states that, holding wages constant, the optimal level of participation is strictly increasing in $\theta$. Therefore, when $\theta<\theta^{\prime}$, it follows that $s_{i}<s_{i}^{\prime}$, and from (11), we have $u_{i}>u_{i}^{\prime}$ for all hirable workers.

When $\theta>\theta^{\prime}$, since $m<m^{\prime}$, it follows that if $m^{\prime}>w_{i}^{N}(\theta)$, then $\max \left\{m, w_{i}^{N}(\theta)\right\}<\max \left\{m^{\prime}, w_{i}^{N}\left(\theta^{\prime}\right)\right\}$, but if $m^{\prime}<w_{i}^{N}(\theta)$, then $\max \left\{m, w_{i}^{N}(\theta)\right\} \geq \max \left\{m^{\prime}, w_{i}^{N}\left(\theta^{\prime}\right)\right\}$ since $w_{i}^{N}(\theta)$ is strictly increasing in $\theta$. This means that for all workers $m^{\prime}<w_{i}^{N}(\theta)$, since now their wages are lower and market tightness is lower, we have that $s_{i}>s_{i}^{\prime}$, and from (11) $u_{i}<u_{i}^{\prime}$. Hirable workers such that $m^{\prime}>w_{i}^{N}(\theta)$, have higher wages although now they participate in a slacker market. The effect of a higher minimum on their participation in ambiguous. Even if the least productive hirable workers increased their participation, more productive workers would still participate in higher rates. The relationship $s_{1} \leq s_{2} \leq, \ldots, \leq s_{n}$ holds at all times.

\section{Appendix B}

\section{Empirical Wage Distribution}

We use wage observations from the monthly CPS from 1997 to 2013 of workers from 16 to 64 years of age. Wages are normalized by their corresponding effective minimum wage and we keep observations between 1 and 3 times the minimum wage since the model assumes full compliance. The observations are divided into 100 class intervals and aggregated using the CPS sample weights. The weighted wage distribution is computed month by month. Monthly distributions are aggregated with equal weights to compute a representative wage distribution across time. This distribution is then smoothed using Hanning smoothing suggested by Tukey (1977); in specific, the STATA 4253eh smoother 
is used twice. Figure 5 shows the distribution. Before the calibration, the empirical wage distribution is normalized so that its mean is equal to one.
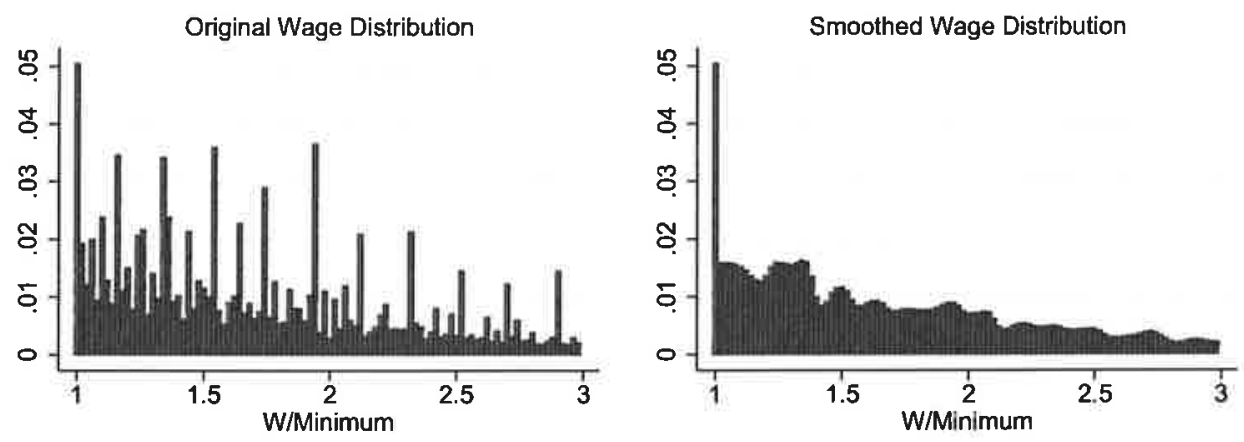

Figure 5: Empirical Wage Distribution

\section{Calibration}

The matching function $h\left(\sum p_{i} s_{i} u_{i}, v\right)=\tau\left(\sum p_{i} s_{i} u_{i}\right)^{\eta} v^{1-\eta}$ implies $f(\theta)=\tau \theta^{1-\eta}$, and $q(\theta)=\tau \theta^{-\eta}$. The average unemployment duration, denoted by $d$, can be expressed as

$$
d=\sum_{i} p_{i} s_{i}\left(\frac{1}{s_{i} f(\theta)}\right)=\frac{\sum_{i} p_{i}}{f(\theta)}=\frac{1}{\tau \theta^{1-\eta}} .
$$

For given values of $\bar{d}, \bar{\theta}$, and $\bar{\eta}$, we use this last expression to determine the efficacy of matching parameter. That is $\tau=\left(\bar{d} \bar{\theta}^{1-\bar{\eta}}\right)^{-1}$. Using (17), aggregate employment, $E m p$, can be expressed as

$$
E m p=\sum_{i} p_{i}\left(1-u_{i}\right)=\sum_{i} p_{i}\left(\frac{s_{i} f(\theta) \Pi_{i}}{\delta+s_{i} f(\theta) \Pi_{i}}\right)=\frac{\sum_{i} p_{i} s_{i}}{\delta+s_{i} f(\theta) \Pi_{i}} d^{-1}
$$

Aggregate labor force participation, $L f p$, is given by

$$
L f p=E m p+\sum_{i} p_{i} s_{i}\left(\frac{\delta}{\delta+s_{i} f(\theta) \Pi_{i}}\right) .
$$


Let $\overline{L f} p$ and $\overline{E m} p$ be the observed statistics. Substituting (18) into (19), we find an expression for the separation rate in terms of observables. That is, $\delta=(\overline{L f} p-E \bar{m} p) /(E \bar{m} p * \bar{d})$. Notice that this last expression guarantees that our aggregate unemployment rate is equal to that implied by $\overrightarrow{L f} p$ and $\overrightarrow{E m} p$. With values for $\tau$ and $\delta$, some specified values $\bar{\alpha}, \bar{b}, \bar{r}$, the observed wage distribution $\left\{w_{i}^{o b s}, p_{i}^{o b s}\right\}_{i=1}^{k}$, and the optimal search intensity condition (4), we find the value for $c_{0}$ that solves (19). Critical for this step, is the fact that $E_{i}-U_{i}$ depends on wages and not worker productivity. This way, although minimum wage earners might have different productivities, their participation intensity is identical and $c_{0}$ can be obtained without specifying a productivity distribution.
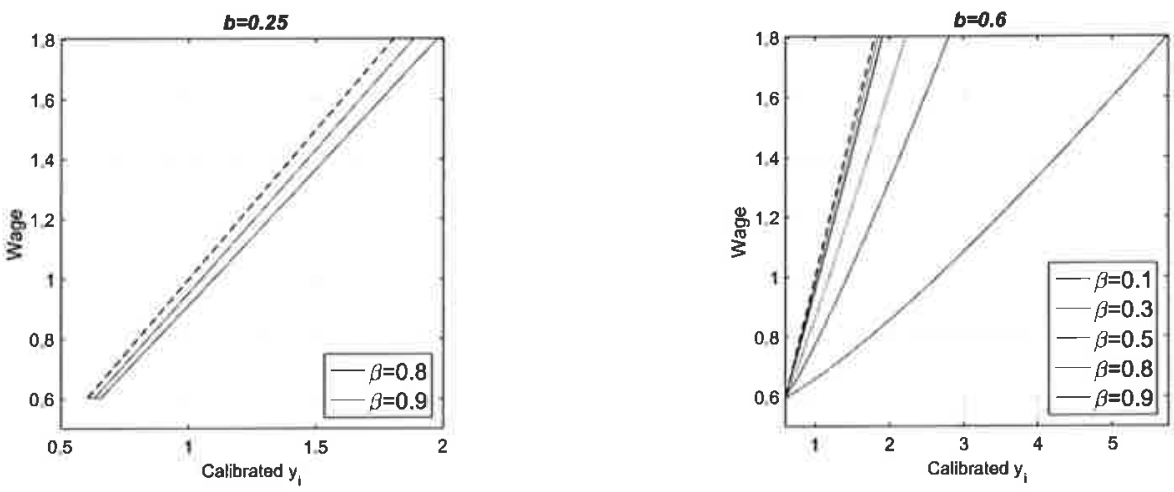

Figure 6: Calibrated Wage Schedules

For a given value $\bar{\beta}$, an implied productivity level can be recovered for each observed wage using (16). $w_{1}^{o b s}$ corresponds to the minimum wage, so according to our model $p_{1}^{\text {obs }}$ is the share of workers with productivities between $m$ and $\bar{y}$. To recover the censored part of the productivity distribution, we assume that $p_{1}^{o b s}$ is distributed uniformly between these two values. With this assumption, we derive the productivity distribution $\left\{y_{j}, p_{j}\right\}_{j=1}^{n}$, with $n \geq k$. With the productivity distribution and the rest of the parameters, we obtain the value of $\gamma$ using the VSC (12) for a given value of $\bar{\theta}$.

All the parameters up to this point, except $\alpha$ and $\beta$, have been selected to meet a specific target. The goal is to find a value of $\alpha$ for each of the values of $\beta$ that we consider, such that an increase of $9 \%$ in $m$ generates an increase of $0.45 \%$ in the employment of the top quintile of the productivity distribution. 

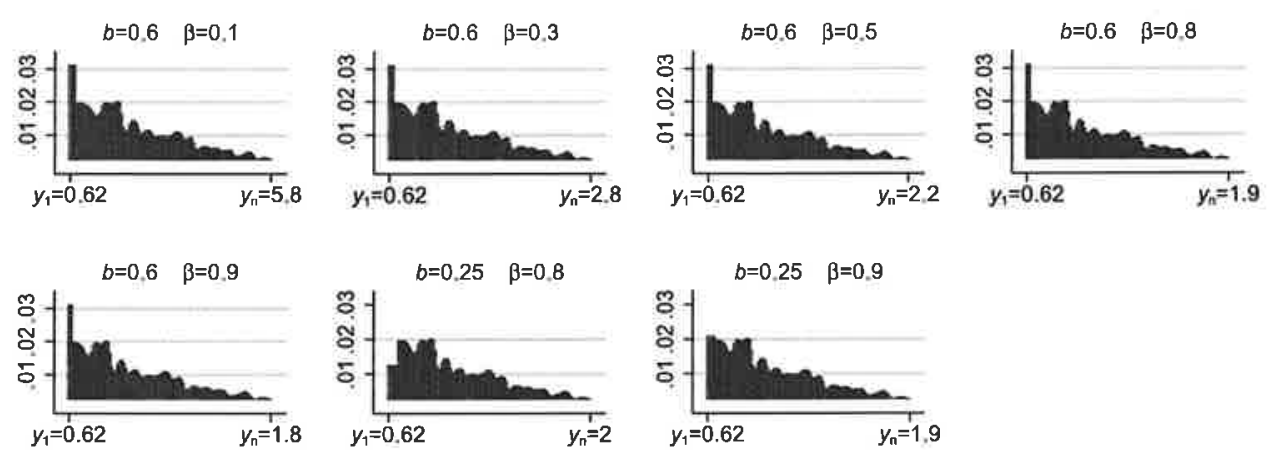

Figure 7: Calibrated Productivity Distributions

The impact that $\alpha$ has on producing the desired elasticity is a priori ambiguous. On the one hand, a higher value lowers the search elasticity of the cost function, and therefore produces stronger search reactions to a tightening in the market. On the other hand, high values increase the cost of search, thus increasing the worker match surplus, and therefore the implied productivity as can be observed in equation (16); for a given wage, a higher $\alpha$ implies a higher productivity-wage wedge, which reduces the trimming effect of a higher minimum and lowers the tightening of the market. In our calibration, it is the latter effect of $\alpha$ that dominates, so as we increase $\beta$, which lowers the implied productivity-wage wedge, $\alpha$ must be adjusted upwards to keep the elasticity of employment constant. When $b=0.6$, we could find a value of $\alpha$ that matches the desired elasticity for any value of $\beta$. However, when $b=0.25$, for any value of $\beta$ below approximately 0.78 , there are no values of $\alpha$ that produce the desired elasticity without missing one of the other targets. 
Table 4: Labor Outcomes by Demographic

\begin{tabular}{|c|c|c|c|c|c|c|c|}
\hline & & Employment & L.F. Participation & U. Duration & Mean Wage & Wage S.D. & Within $10 \%$ of MW \\
\hline LTHS & $\begin{array}{l}16-19 \\
20-24 \\
25-44 \\
46-64\end{array}$ & $\begin{array}{l}0.3 \\
0.53 \\
0.62 \\
0.48\end{array}$ & $\begin{array}{c}0.37 \\
0.66 \\
0.7 \\
0.53\end{array}$ & $\begin{array}{l}0.97 \\
1.54 \\
1,64 \\
1.96\end{array}$ & $\begin{array}{l}1.17 \\
1,45 \\
1.7 \\
1.83\end{array}$ & $\begin{array}{c}0.4 \\
0.59 \\
0.8 \\
0.88\end{array}$ & $\begin{array}{l}0.51 \\
0.25 \\
0.16 \\
0.14\end{array}$ \\
\hline HS & $\begin{array}{l}18-18 \\
20-24 \\
25-44 \\
48-64\end{array}$ & $\begin{array}{c}0.5 \\
0.69 \\
0.76 \\
0.67\end{array}$ & $\begin{array}{c}0.6 \\
0.79 \\
0.82 \\
0.7\end{array}$ & $\begin{array}{l}1.05 \\
1.43 \\
1.66 \\
1.96\end{array}$ & $\begin{array}{l}1.33 \\
1.59 \\
2.17 \\
2.93\end{array}$ & $\begin{array}{c}0.55 \\
0.7 \\
1.05 \\
1.11\end{array}$ & $\begin{array}{l}0.32 \\
0.17 \\
0.07 \\
0.05\end{array}$ \\
\hline sc & $\begin{array}{l}18-18 \\
20-24 \\
25-44 \\
46-64\end{array}$ & $\begin{array}{l}0.52 \\
0.66 \\
0.79 \\
0.72\end{array}$ & $\begin{array}{l}0.58 \\
0.71 \\
0.84 \\
0.75\end{array}$ & $\begin{array}{l}0.84 \\
1.07 \\
1.59 \\
1.99\end{array}$ & $\begin{array}{l}1.31 \\
1.49 \\
2.26 \\
2.55\end{array}$ & $\begin{array}{l}0.52 \\
0.64 \\
1.11 \\
1.25\end{array}$ & $\begin{array}{l}0.32 \\
0.21 \\
0.07 \\
0.04\end{array}$ \\
\hline C & $\begin{array}{l}20-24 \\
25-44 \\
46-64\end{array}$ & $\begin{array}{l}0.79 \\
0.85 \\
0.78\end{array}$ & $\begin{array}{l}0.84 \\
0.88 \\
0.81\end{array}$ & $\begin{array}{l}1.04 \\
1.55 \\
2.04\end{array}$ & $\begin{array}{l}1.86 \\
2.79 \\
3.04\end{array}$ & $\begin{array}{l}0.88 \\
1.54 \\
1.72\end{array}$ & $\begin{array}{l}0.11 \\
0.04 \\
0.03\end{array}$ \\
\hline A & $\begin{array}{l}26-44 \\
46-64\end{array}$ & $\begin{array}{l}0.89 \\
0.84\end{array}$ & $\begin{array}{l}0.91 \\
0.86\end{array}$ & $\begin{array}{l}1.52 \\
2.11\end{array}$ & $\begin{array}{l}3.76 \\
4.05\end{array}$ & $\begin{array}{c}2.34 \\
2.6\end{array}$ & $\begin{array}{l}0.03 \\
0.03\end{array}$ \\
\hline
\end{tabular}

This table shows labor market outcomes for the different demographics diaggregating by age and education (two-way). The outcomes are the employment rate, the labor force participation rate, average unemployment duration in quarters, the average and the standard 2013.

Table 5: Minimum Wage Elasticities, Aggregates

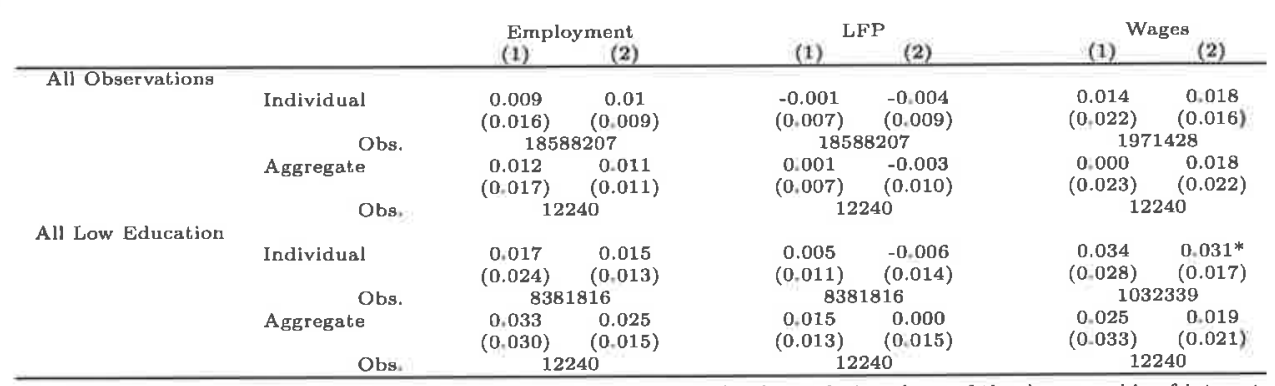

All regressions include state-level quarterly per-capita income, state-level population share of the demographic of interest, and statc-fixed cffects. Specification (1) additionally includes timc-fixed effects and specification (2) additionally includes census-dicion specific time-effects; and state-specife linear trends. Standard errors clustert at slate level are reported in parentheses signifor partion, gender, race, and move paridip the a 作 end the log of the weighted average hourly wage. 
Table 6: Minimum Wage Elasticities, One-way Dissagregation

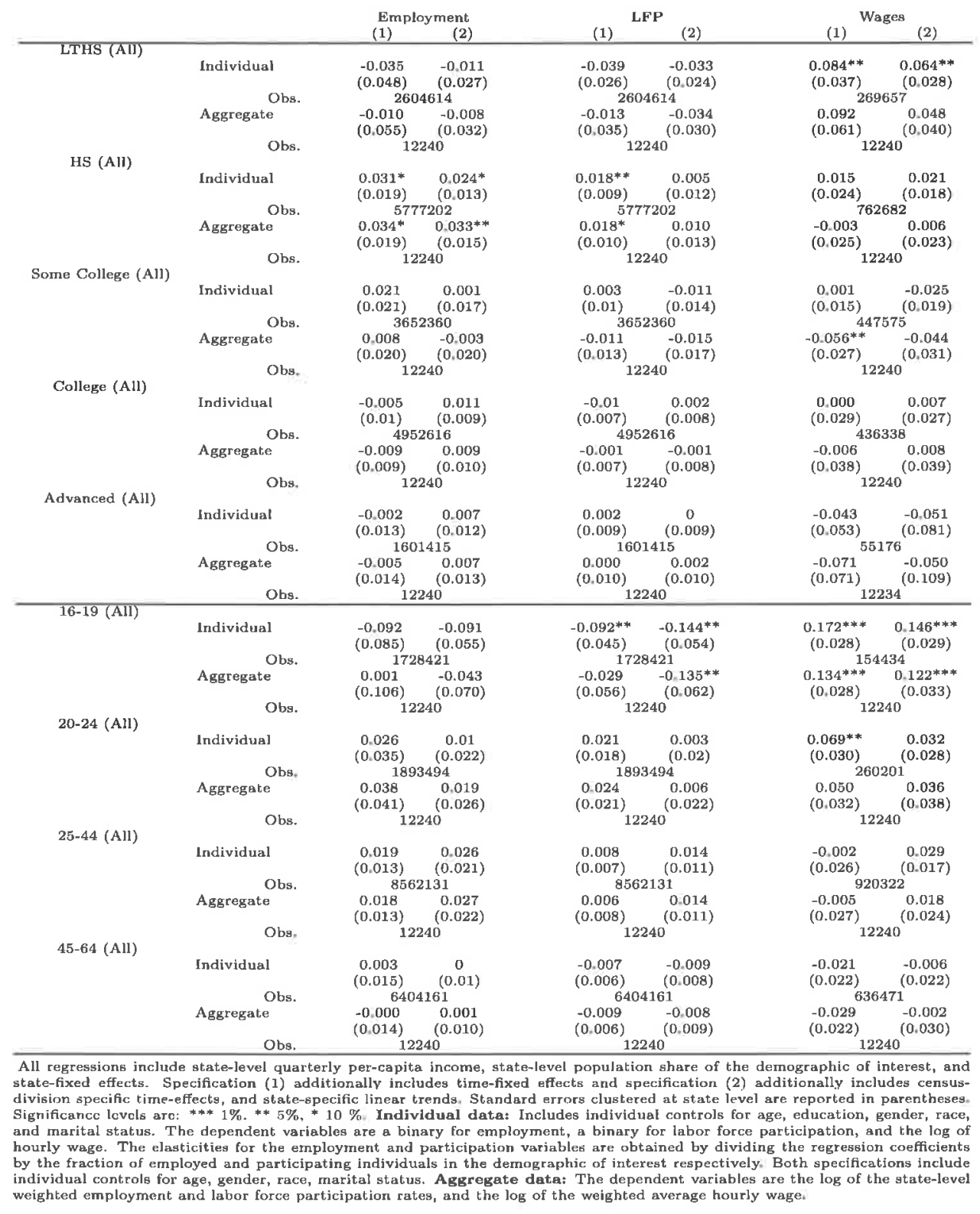


Table 7: Minimum Wage Elasticities, Two-way disaggregation

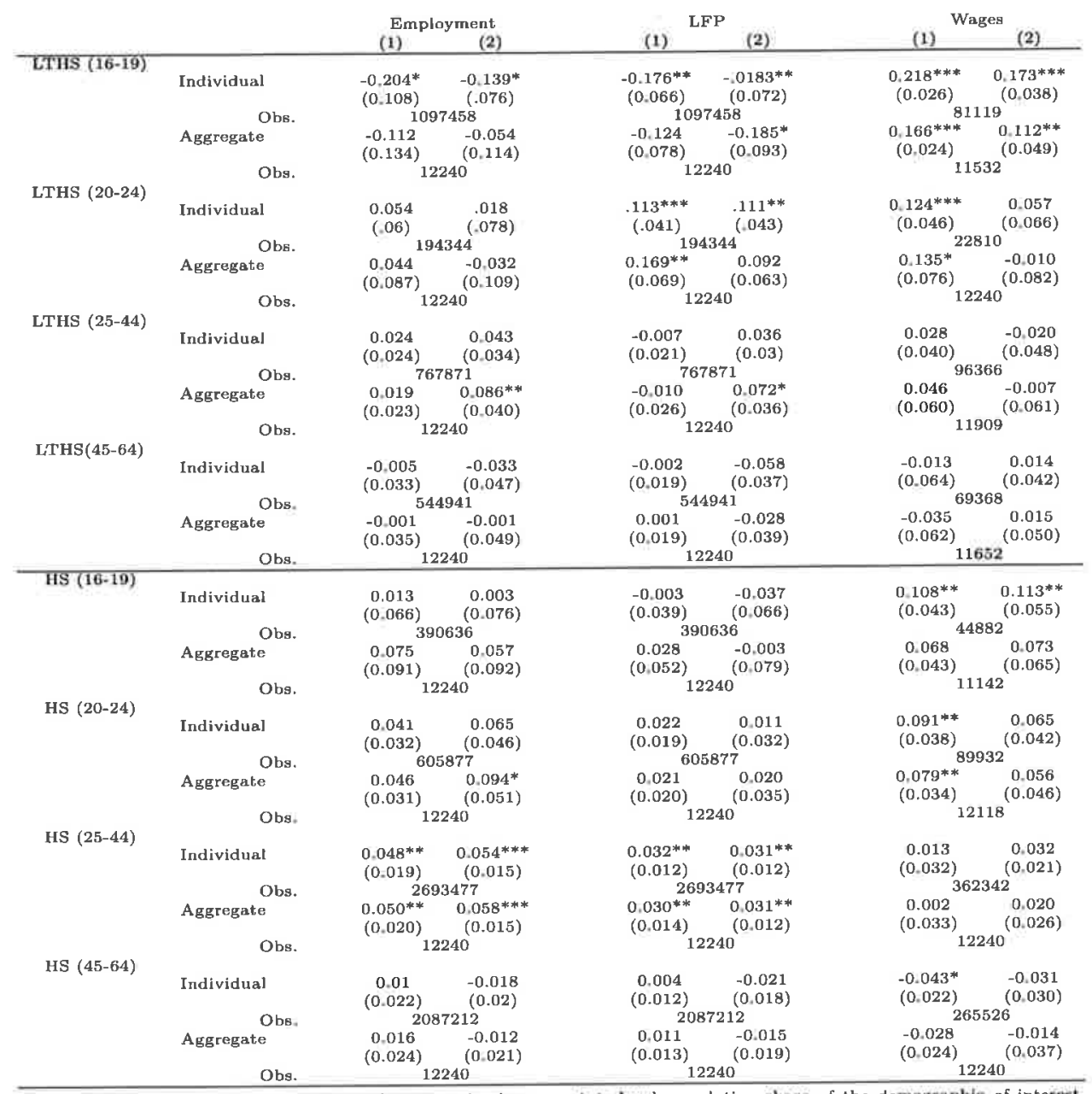

All regressions include state-level quarterly per-capita income, state-lovel population share of the demographic of interest, and state-fixed effects. Specification (1) additionally includes time-fixed effects and specification (2) additionally includes census-division specific time-effects, and state-specific linear tronds. Standard errors clustered at state level are reported it parentheses. Significance levels are: $* * * 1 \%, * 5 \%, 10 \%$. Individual data: Includes individual controls for age, education, gender, race, and marital status. The dependent variables are a binary for employment, a binary for labor force participation, and the log of hourly wage. The elasticities for the employment and participation variables aro obtained by dividing the regression coefficients by the fraction of employed and participating individuals in the demographic of interest respectively. Both specifications include individual controis for age, gender, race, tharital status. Aggregate data: The dependent variables are the log of the state-level weighted employment and labor forco participation rates, and the log of the weighted average hourly wage. 
Table 8: Minimum Wage Elasticities, Two-way disaggregation

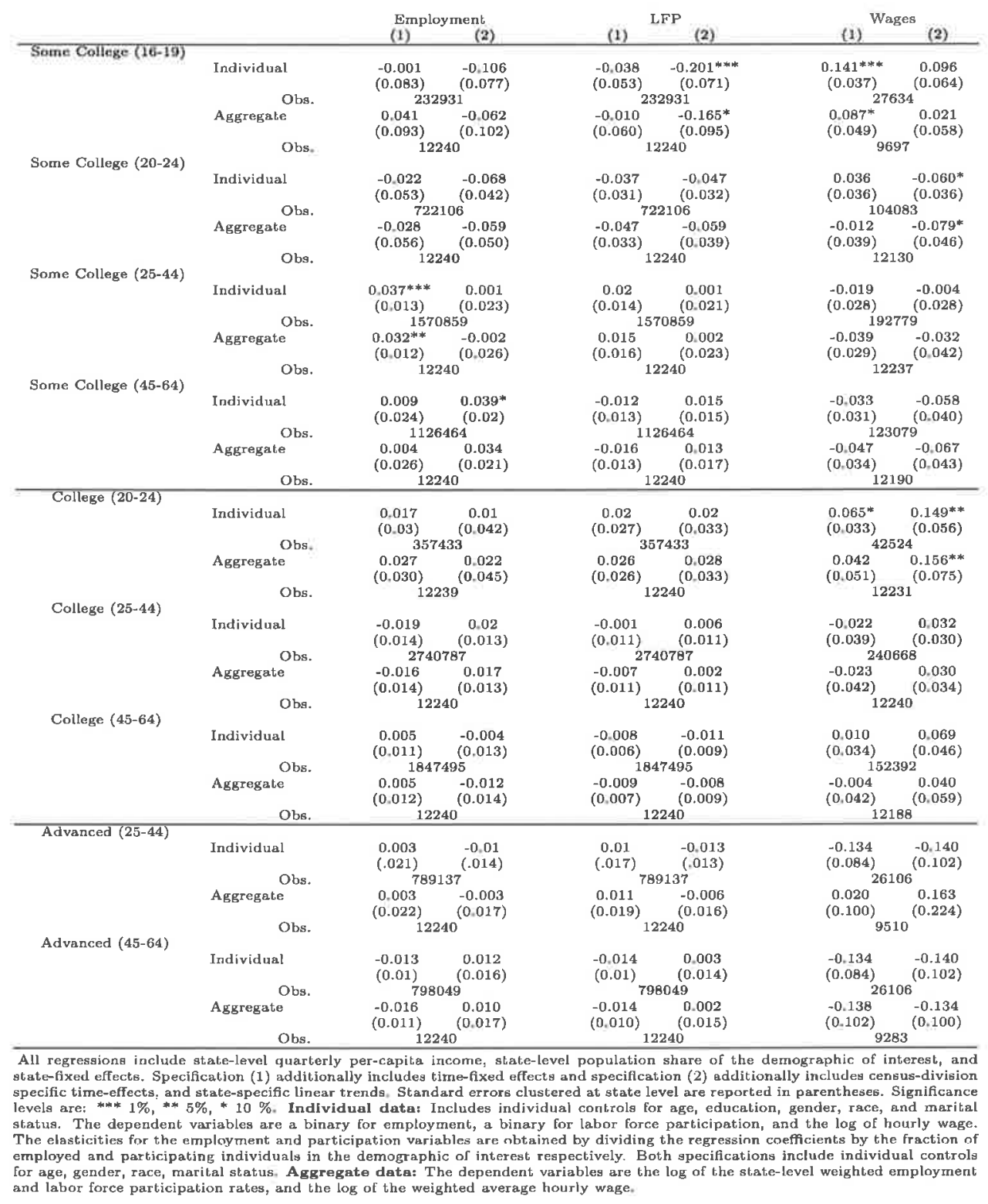




\begin{abstract}
Abstrakt
Tento článek zkoumá hypotézu, že minimální mzdy ovlivňují různé pracovníky s nízkou kvalifikací asymetricky $\mathrm{z}$ důvodu rozdílné produktivity. V modelech vyhledávání (search model) s heterogenními pracovníky zvýšení minimální mzdy snižuje zaměstnanost a ekonomickou aktivitu u nejméně produktivních pracovníkủ. Efekt je způsoben špatnou zaměstnatelností, která je dána vysokou cenou práce. Opačný efekt se projevuje u ostatních pracovníků s nízkou kvalifikací, kteří zůstanou i po změně minimální mzdy zaměstnatelní. CPS data podporují tyto předpovědi. Zvýšení minimální mzdy snižuje zaměstnanost a ekonomickou aktivitu náctiletých s nižším než středoškolským vzděláním, ale projevuje se opačně u pracovníků středního věku se středoškolským vzděláním. Model, který kalibrujeme, vyžaduje malý přebytek firmy k dosažení shody s empirickými výsledky. Pokud je přebytek firmy malý v důsledku vysokých hodnot netržních aktivit, pak mírné zvýšení minimální mzdy zvyšuje agregátní blahobyt i v situacích, kdy je vyjednávací síla pracovníků vysoká.
\end{abstract}


Working Paper Series

ISSN 1211-3298

Registration No. (Ministry of Culture): E 19443

Individual researchers, as well as the on-line and printed versions of the CERGE-EI Working Papers (including their dissemination) were supported from institutional support RVO 67985998 from Economics Institute of the CAS, v. v. i.

Specific research support and/or other grants the researchers/publications benefited from are acknowledged at the beginning of the Paper.

(c) Jose Luis Luna-Alpizar, 2019

All rights reserved. No part of this publication may be reproduced, stored in a retrieval system or transmitted in any form or by any means, electronic, mechanical or photocopying, recording, or otherwise without the prior permission of the publisher.

Published by

Charles University, Center for Economic Research and Graduate Education (CERGE)

and

Economics Institute of the CAS, v. v. i. (EI)

CERGE-EI, Politických vězňủ 7, 11121 Prague 1, tel.: +420 224005 153, Czech Republic.

Printed by CERGE-EI, Prague

Subscription: CERGE-EI homepage: http://www.cerge-ei.cz

Phone: + 420224005153

Email: office@cerge-ei.cz

Web: http://www.cerge-ei.cz

Editor: Byeongju Jeong

The paper is available online at http://www.cerge-ei.cz/publications/working_papers/.

ISBN 978-80-7343-449-6 (Univerzita Karlova, Centrum pro ekonomický výzkum

a doktorské studium)

ISBN 978-80-7344-502-7 (Národohospodářský ústav AV ČR, v. v. i.) 